\title{
NEEM to EastGRIP Traverse - spatial variability, seasonality, extreme events and trends in common ice core proxies over the past decades.
}

5 Vallelonga ${ }^{1,3}$

Helle Astrid Kjær ${ }^{1}$, Patrick Zens ${ }^{1}$, Samuel Black ${ }^{1,2}$, Kasper Holst Lund ${ }^{1}$, Anders Svensson ${ }^{1}$ and Paul 1 Physics for Ice, Climate and Earth Sciences (PICE), Niels Bohr Institute, University of Copenhagen, Copenhagen 2100, Denmark

2 NatureScot, Inverness, IV3 8NW, United Kingdom

10

3 UWA Oceans Institute, University of Western Australia, Crawley, WA, Australia

Correspondence to: Helle Astrid Kjær (Hellek@fys.ku.dk)

\begin{abstract}
.
Greenland ice cores provide information about past climate. However, the number of firn and ice cores from Greenland are limited and thus the spatial variability of the chemical impurities used as proxies is largely unconstrained. Furthermore, few 15 impurity records covering the past two decades exist from Greenland. We have by means of Continuous Flow analysis investigated 6 shallow firn cores obtained in Northern Greenland as part of the NEEM to EastGRIP traverse in 2015. The oldest reach back to 1966 .

The annual mean and quartiles of the insoluble dust, ammonium, and calcium concentrations in the 6 firn cores spanning a distance of $426 \mathrm{~km}$ overlap, and also the seasonal cycles have similar peaks in timing and magnitude across sites. Peroxide

$20\left(\mathrm{H}_{2} \mathrm{O}_{2}\right)$ is accumulation dependent and varies from site to site and conductivity, likely influenced by sea salts, also vary spatially.

The temporal variability of the records is further assessed. We find no evidence for increases in total dust concentration, but find an increase in the large dust particle fluxes that we contribute to an activation of Greenland local sources in the recent years (1998-2015). We observe the expected acid and conductivity increase in the mid 70's as a result of anthropogenic

25 contamination and the following decrease due to mitigation. After detrending using the five year average the conductivity and acid records several volcanic horizons were identified and associated with Icelandic eruptions and volcanic eruptions in the Barents sea region.

By creating a composite based on excess ammonium compared to the five year running average, we obtain a robust forest fire proxy associated primarily with Canadian forest fires $(\mathrm{R}=0.51)$. We also note that the peak ammonium in the individual firn 30 cores appear more scattered between cores than the peak volcanic layers, suggesting that the forest fire signal is more dispersed in the atmosphere than the acid from volcanic eruptions.
\end{abstract}




\section{Introduction}

The accumulation and preservation of past snowfall as glacier ice stores an abundance of information regarding past environmental conditions that can be retrieved through intricate physical and chemical analyses of polar ice cores.

For Greenland, water isotopes and deuterium excess can provide information on average temperatures and ice volumes

5 (Johnsen et al., 1989; Dansgaard, 1964), dust layers provide constrains on large scale atmospheric circulation patterns and desertification (Fischer et al., 2007; Ruth et al., 2002; Marius Folden Simonsen et al., 2019), sodium and other sea salts further constrain atmospheric transport, while simultaneously informing on oceanic conditions (Schüpbach et al., 2018; Fischer et al., 2007; Rhodes et al., 2018), and ammonium peak concentrations provide evidence of forest fire activity and global vegetation coverage (e.g. Legrand et al., 1992; Legrand et al., 2016). Often these proxies exhibit annual cycles in the composition and

10 concentration due to natural cycles in their atmospheric concentration but also as a result of temperature, accumulation and wind fluctuations at deposition site. These annual peaks and cycles can be used to identify corresponding annual layers in the ice important for dating the high resolution climatic signals (Rasmussen et al., 2013; Svensson et al., 2008)

The development of high resolution continuous flow analysis (CFA) techniques (Kaufmann et al., 2008; Bigler et al., 2011;

15 Dallmayr et al., 2016; Kjær et al., 2021a) has facilitated continuous long-term paleoclimate records back through time on a sub-annual scale (Schüpbach et al., 2018; Marius Folden Simonsen et al., 2019) and is now a standard in ice core analyses. CFA represents a highly efficient and rapid analysis technique relative to the measurement of discrete samples and is favoured for the effective sample decontamination and high sampling resolution.

To improve the understanding and constrain the proxies commonly analysed by means of CFA, we here evaluate the impurity

20 concentrations in six shallow Northern Greenland firn cores, their seasonal cycles, temporal and spatial trends and extremes. The sites chosen represent the lower accumulation area in the central North Greenland and has only limited prior analysis of this kind (Du et al., 2019; Vallelonga et al., 2014; Fischer et al., 1998; Gfeller et al., 2014; Schüpbach et al., 2018; Kjær et al., 2021a).

\section{Methods}

25 Six shallow firn cores were collected during the Neem to EGRIP (N2E) traverse in May-June (Karlsson et al., 2020). The traverse went from the NEEM deep ice core drill site $\left(77 \mathrm{~N} 25.219^{\prime}, 51 \mathrm{~W} 09.588^{\prime}\right)$ to the EastGRIP deep ice core drill site (75N37.501',35W58.809'). Cores were drilled from the surface to a depth between $9.08 \mathrm{~m}$ and $14.01 \mathrm{~m}$. The position and time period covered by the firn cores labelled T2015-A1 to T2015-A6 can be found in Table 1 and Figure 1 (Kjær et al., 2021b). The firn cores were drilled using the American IDDO (U.S. Ice Drilling and Design Operations) hand auger (76 mm diameter).

30 In the field the cores were split into $55 \mathrm{~cm}$ long segments and packed into plastic bags. They were transported in cooler boxes on sledges to the EastGRIP site, from where they were flown first to Kangerlussuaq, Greenland and then shipped further to 
Copenhagen, Denmark for analysis. In Copenhagen they were stored at $-20^{\circ} \mathrm{C}$ until further cutting into sections of $3.4 \times 3.4$ cm just prior to measurements by CFA (Bigler et al. 2011).

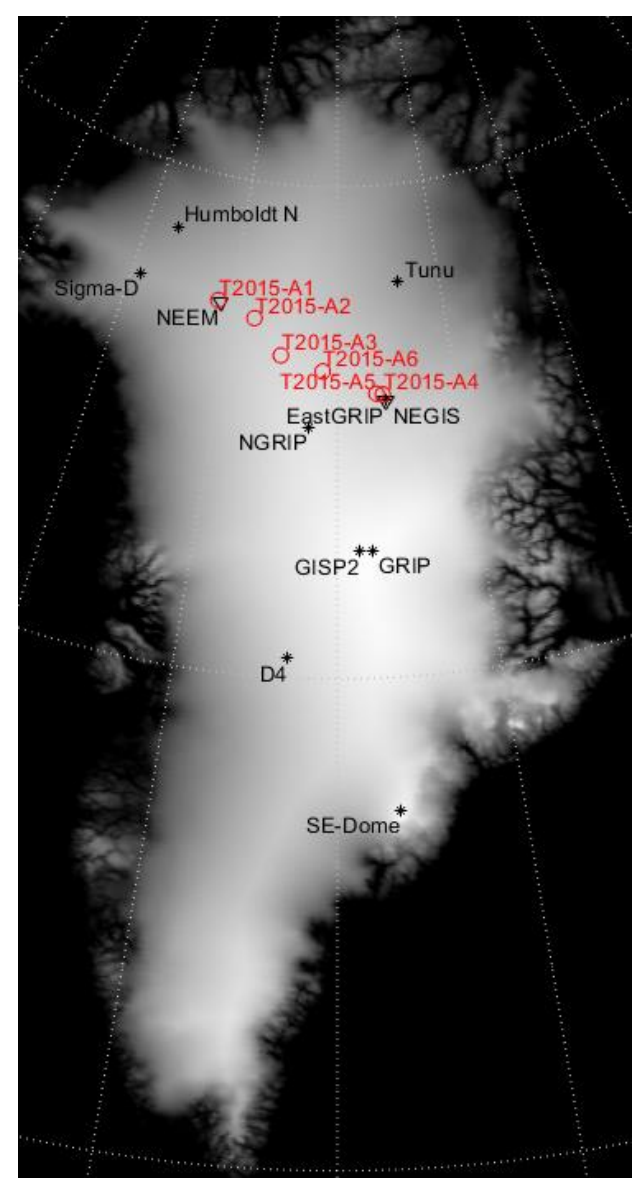

5 Figure 1: Greenland surface elevation (SeaRISE dataset, Bamber, 2001) and the 6 drill sites for the shallow firn cores investigated in this study (red circles) and the sites of other ice and firn cores mentioned in this study (black stars) .

Table 1. Name, Latitude, Longitude, Altitude, lengths, Bottom age and mean accumulation (Kjær et al., 2021b) of the shallow firn cores presented in this study. The firn cores are labelled 2015T-A1 (NEEM ice core drilling site) to 2015T-A5 (EastGRIP drilling site). All cores were drilled in 2015 and measured by means of CFA in Copenhagen in 2017.

\begin{tabular}{|c|c|c|c|c|c|c|}
\hline \multirow{2}{*}{$\begin{array}{c}\text { Firn core } \\
\text { ID }\end{array}$} & \multicolumn{2}{|c|}{ Coordinates } & \multirow{2}{*}{$\begin{array}{c}\text { Altitude } \\
\text { m a.s.l. }\end{array}$} & \multirow{2}{*}{$\begin{array}{c}\text { Depth } \\
\text { of core } \\
\text { m }\end{array}$} & \multirow{2}{*}{$\begin{array}{c}\text { Time period } \\
\text { covered } \\
\text { AD }\end{array}$} & \multirow{2}{*}{$\begin{array}{c}\text { Mean annual } \\
\text { accumulation } \\
\mathrm{cm} \text { w.eq } \mathrm{a}^{-}\end{array}$} \\
\hline & $\mathrm{N}$ & $\mathrm{W}$ & & & & \\
\hline 2015T-A1 (NEEM) & $77 N^{\prime 25.219 '}$ & 51W09.588' & 2484 & 9.08 & $2015-1998( \pm 1)$ & $22.2 \pm 5.6$ \\
\hline 2015T-A2 & 77N01.764' & 47W28.832' & 2620 & 10.74 & $2015-1988( \pm 1)$ & $17.6 \pm 5.0$ \\
\hline
\end{tabular}




\begin{tabular}{lllllll} 
2015T-A3 & 76N27.290' & $44 \mathrm{~W}^{\prime} 47.709^{\prime}$ & 2771 & 10.97 & $2015-1988( \pm 0)$ & $17.5 \pm 2.8$ \\
2015T-A4 & $75 N 41.340^{\prime}$ & $36 \mathrm{~W} 28.926^{\prime}$ & 2701 & 10.91 & $2015-1982( \pm 2)$ & $11.8 \pm 2.2$ \\
2015T-A5 (EGRIP) & $75 N 37.501^{\prime}$ & $35 \mathrm{~W} 58.809^{\prime}$ & 2708 & 14.02 & $2015-1966( \pm 2)$ & $14.6 \pm 3.1$ \\
2015T-A6 & $76 N 10.294^{\prime}$ & $41 \mathrm{~W} 05.628^{\prime}$ & 2760 & 12.07 & $2015-1968( \pm 3)$ & $13.7 \pm 4.2$ \\
\hline
\end{tabular}

\subsection{Continuous flow analysis (CFA)}

The CFA system at the Niels Bohr Institute in Copenhagen (Bigler et al., 2011) was used to analyse the 6 firn cores for their chemical impurity content in 2017. The system was slightly adapted from the published Copenhagen CFA system (Bigler et al., 2011), which determines conductivity $(\sigma)$, insoluble dust, ammonium $\left(\mathrm{NH}_{4}^{+}\right)$and calcium $\left(\mathrm{Ca}^{2+}\right)$ by adding analysis of hydrogen peroxide $\left(\mathrm{H}_{2} \mathrm{O}_{2}\right)$ and acid (Kjær et al., 2016). The flow chart and additional information for the particular CFA setup and instrumentation is presented in the supplementary material (Figure S1, Tables S1 to S3).

The determined signals were converted to a concentration using a linear regression produced by a set of two $\left(\mathrm{H}_{2} \mathrm{O}_{2}\right.$ and acid) or three $\left(\mathrm{NH}_{4}{ }^{+}\right.$and $\left.\mathrm{Ca}^{2+}\right)$ known standards. Calibrations were performed every four hours. Baseline was established by running

10 milliq water through the system for every $4.4 \mathrm{~m}$ (8eight $55 \mathrm{~cm}$ pieces stacked). Although, for the top 1.65 metre where the core was fragile as a result of low density, baseline was established in between each of the top three $55 \mathrm{~cm}$ sections to ensure baseline stability and avoid compression from overlying cores increasing the uncertainty on the depth registration.

Due to capillary forces the firn has a tendency to suck water from the melt head up into the snow, dispersing the signal. This was mitigated by adding a metal coin to the melt head to limit contact between any excess meltwater on the melt head and the

15 firn core. In addition, excess water that could be sucked up into the firn was limited to $0.5-1 \mathrm{~cm}$ by carefully adjusting melt head temperature relative to pump speeds carrying the water away. Melt rate was kept at $\sim 4 \mathrm{~cm} / \mathrm{min}$ which resulted in the final depth resolution of the ions measured being $<2 \mathrm{~cm}$ (acidity, $\mathrm{NH}^{++}, \mathrm{H}_{2} \mathrm{O}_{2}, \mathrm{Ca}^{2+}$ ), while for the conductivity and dust with a shorter response time a depth resolution of $8 \mathrm{~mm}$ was achieved.

\subsection{Core chronology}

20 Several proxies in Greenland snow and ice cores show a seasonal cycle if analysed in sufficient resolution (Gfeller et al., 2014) used to constrain the annual layers and thus the age of the firn cores (Svensson et al., 2008; Winstrup et al., 2019). The production of peroxide $\left(\mathrm{H}_{2} \mathrm{O}_{2}\right)$ mainly takes place during months of intense insolation as it produced by a photochemical derived self-reaction of hydroperoxyl radicals $\left(\mathrm{HO}_{2}\right)$ (Frey et al., 2006; Sigg and Neftel, 1988). Therefore, $\mathrm{H}_{2} \mathrm{O}_{2}$ records show maximum concentrations in the summer and minimum concentrations during the winter months, when photochemical processes are absent at polar latitudes (Sigg and Neftel, 1988; Frey et al., 2006). However, $\mathrm{H}_{2} \mathrm{O}_{2}$ maintain a constant exchange with the atmosphere, leading to post-depositional relocation within the upper snow and firn. Thus if snow accumulation rates are not sufficiently high enough ( $0.13 \mathrm{~m}$ w.eq. $\left.\mathrm{a}^{-1}\right)$, this can cause smoothing and loss of seasonal $\mathrm{H}_{2} \mathrm{O}_{2}$ signals (Neftel, 1996). 
https://doi.org/10.5194/cp-2021-99

Preprint. Discussion started: 16 August 2021

(c) Author(s) 2021. CC BY 4.0 License.

(c) (1)

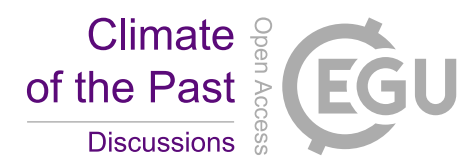

We rely on the strong seasonal pattern of $\mathrm{H}_{2} \mathrm{O}_{2}$ to constrain the age of the 6 shallow cores (Table 1), where we assign the summer peak of peroxide to solar solstice (June). At the low accumulation sites where peroxide seasonality was not well resolved; 2015T-A6, 2015T-A4 and 2015T-A5, the seasonality in $\mathrm{Ca}^{2+}$ was invoked to further constrain the firn core chronologies. T2015-A5 (EastGRIP site) reaches furthest back in time to the mid 1960's, while the youngest core (T2015-A1-

5 NEEM site) covers the period 1997 to 2015.

To investigate the seasonality in the proxies the year was split further into 12 months of equal accumulation using the formal month definition (Gfeller et al., 2014; Kjær et al., 2013). Instead we could have used re-analysis accumulation data to constrain the monthly accumulation, but even high-resolution weather re-analysis performs poorly on the central ice sheet (Kjær et al., 2021b) and thus we stick with a simple constant accumulation scenario. We have not used the extreme peaks of acid nor

10 ammonium to constrain the dating between the 6 firn cores and thus each core is dated on its own individual timescale using solely annual layer counting of $\mathrm{H}_{2} \mathrm{O}_{2}$ and for T2015-A6, T2015-A5, T2015-A4 also $\mathrm{Ca}^{2+}$.

\section{Spatial variability}

In Figure 2 the chemical profiles from the CFA campaign is presented for all six firn cores and Table 2 presents the median and the $15 \%$ and $85 \%$ quantiles for each of the impurities in each of the cores. 




Figure 2. Proxies measured by means of CFA in the six shallow firn cores; T2015-A1(yellow), T2015-A2(purple), T2015-A3 (cyan), T2015-A4 (blue), T2015-A5 (red) and T2015-A6 (green). From the top is shown conductivity, acid, insoluble dust, calcium, ammonium and peroxide concentrations. Note that for T2015-A1 the acid and for T2015-A5 the ammonium was not of sufficient quality and thus not shown.

\begin{tabular}{|c|c|c|c|c|c|c|c|c|c|c|c|c|}
\hline & \multicolumn{6}{|c|}{ Full period } & \multicolumn{6}{|c|}{2000 onwards } \\
\hline & $\begin{array}{l}\text { T2015- } \\
\text { A1 }\end{array}$ & $\begin{array}{l}\text { T2015- } \\
\text { A2 }\end{array}$ & $\begin{array}{l}\text { T2015- } \\
\text { A3 }\end{array}$ & $\begin{array}{l}\text { T2015- } \\
\text { A4 }\end{array}$ & $\begin{array}{l}\text { T2015- } \\
\text { A5 }\end{array}$ & $\begin{array}{l}\text { T2015- } \\
\text { A6 }\end{array}$ & $\begin{array}{l}\text { T2015- } \\
\text { A1 }\end{array}$ & $\begin{array}{l}\text { T2015- } \\
\text { A2 }\end{array}$ & $\begin{array}{l}\text { T2015- } \\
\mathrm{A} 3\end{array}$ & $\begin{array}{l}\text { T2015- } \\
\text { A4 }\end{array}$ & $\begin{array}{l}\text { T2015- } \\
\text { A5 }\end{array}$ & $\begin{array}{l}\text { T2015- } \\
\text { A6 }\end{array}$ \\
\hline \multirow{3}{*}{$\begin{array}{l}\text { Dust } \\
(\# / m L)\end{array}$} & 32.9 & 32.9 & 34.0 & 37.4 & 39.7 & 35.1 & 35.7 & 44.5 & 37.4 & 39.1 & 50.4 & 38.3 \\
\hline & 91.0 & 87.2 & 79.2 & 95.3 & 96.4 & 78.2 & 95.0 & 89.9 & 95.8 & 94.6 & 104.8 & 79.2 \\
\hline & 239.9 & 198.3 & 191.5 & 271.9 & 248.8 & 194.3 & 243.2 & 188.8 & 200.1 & 270.5 & 261.8 & 195.6 \\
\hline \multirow{3}{*}{$\begin{array}{l}\text { Calcium } \\
\text { (ppb) }\end{array}$} & 2.2 & 1.8 & 1.3 & 2.7 & 2.2 & 2.9 & 2.2 & 1.3 & 2.0 & 2.3 & 2.6 & 2.9 \\
\hline & 4.5 & 4.3 & 3.4 & 6.1 & 4.2 & 5.6 & 4.5 & 3.5 & 4.6 & 5.3 & 4.7 & 5.2 \\
\hline & 8.8 & 9.0 & 8.2 & 13.3 & 9.9 & 11.1 & 8.6 & 7.5 & 9.0 & 13.1 & 10.1 & 9.8 \\
\hline
\end{tabular}




\begin{tabular}{|l|rrrrrr|rrrrrr|}
$\mathrm{H}_{2} \mathrm{O}_{2}$ & 68 & 76 & 72 & 33 & 27 & 29 & 66 & 77 & 68 & 27 & 32 & 34 \\
$(\mathrm{ppb})$ & $\mathbf{1 1 0}$ & $\mathbf{9 9}$ & $\mathbf{9 6}$ & $\mathbf{5 5}$ & $\mathbf{3 9}$ & $\mathbf{4 9}$ & $\mathbf{1 1 0}$ & $\mathbf{1 0 0}$ & $\mathbf{1 0 1}$ & $\mathbf{4 5}$ & $\mathbf{5 7}$ & $\mathbf{5 4}$ \\
& 148 & 130 & 132 & 75 & 67 & 84 & 151 & 133 & 150 & 78 & 83 & 96 \\
\hline $\mathrm{NH} 4$ & 2.2 & 5.6 & 3.3 & 2.5 & & 3.2 & 2.2 & 4.9 & 4.3 & 2.2 & & 2.8 \\
$(\mathrm{ppb})$ & $\mathbf{5 . 8}$ & $\mathbf{1 1 . 6}$ & $\mathbf{7 . 0}$ & $\mathbf{5 . 1}$ & & $\mathbf{6 . 0}$ & $\mathbf{5 . 8}$ & $\mathbf{1 1 . 5}$ & $\mathbf{8 . 0}$ & $\mathbf{4 . 9}$ & & $\mathbf{6 . 2}$ \\
& 10.8 & 25.7 & 12.6 & 10.6 & & 11.2 & 10.9 & 26.0 & 13.6 & 10.7 & & 11.0 \\
\hline $\mathrm{H}+$ & 3.26 & 0.65 & 1.88 & 0.86 & 0.58 & 0.53 & 3.64 & 0.85 & 1.52 & 1.07 & 0.38 & 0.90 \\
$(\mathrm{uM})$ & $\mathbf{5 . 6 7}$ & $\mathbf{2 . 6 5}$ & $\mathbf{3 . 2 4}$ & $\mathbf{2 . 0 3}$ & $\mathbf{2 . 2 1}$ & $\mathbf{2 . 3 4}$ & $\mathbf{6 . 0 5}$ & $\mathbf{2 . 8 1}$ & $\mathbf{2 . 6 3}$ & $\mathbf{2 . 0 6}$ & $\mathbf{1 . 7 4}$ & $\mathbf{2 . 6 7}$ \\
& 8.45 & 4.40 & 4.78 & 4.10 & 4.33 & 4.23 & 8.64 & 4.22 & 4.30 & 4.13 & 3.22 & 4.35 \\
\hline $\mathrm{Conducti}$ & & & & & & & & & & & & 1.51 \\
vity & 1.29 & 1.28 & 1.41 & 1.54 & 1.77 & 1.70 & 1.28 & 1.27 & 1.33 & 1.40 & 1.60 & 1.51 \\
$(\mathrm{uS} / \mathrm{cm})$ & $\mathbf{1 . 6 7}$ & $\mathbf{1 . 6 8}$ & $\mathbf{1 . 7 3}$ & $\mathbf{2 . 0 1}$ & $\mathbf{2 . 2 3}$ & $\mathbf{2 . 1 7}$ & $\mathbf{1 . 6 7}$ & $\mathbf{1 . 6 5}$ & $\mathbf{1 . 6 5}$ & $\mathbf{1 . 7 4}$ & $\mathbf{1 . 9 2}$ & $\mathbf{1 . 9 3}$ \\
& 2.02 & 2.15 & 2.22 & 2.69 & 2.92 & 3.05 & 2.02 & 1.99 & 2.11 & 2.16 & 2.34 & 2.34 \\
\hline
\end{tabular}

Table 2: Concentrations of impurities. $15 \%$, median (50\%) and $85 \%$ quantiles based on the monthly mean records for each of the compounds analysed is shown for each of the 6 traverse cores. $15 \%$ and $85 \%$ shown in italic. Left for the full temporal record and right for the period $2000 \mathrm{AD}$ and onwards to make comparable estimates between sites.

5 The annual variability in the individual records is large for all proxies and spatial concentration variability between sites is masked for insoluble dust, $\mathrm{Ca}_{2}{ }^{+}, \mathrm{NH}_{4}{ }^{+}, \mathrm{H}^{+}$, and conductivity by the temporal variation in local characteristics and does not vary significantly over a $426 \mathrm{~km}$ traverse in Northern Greenland, despite the accumulation being double or more in the northwest (T2015-A1, T2015-A2, T2015-A3) compared to the central north and northeast (T2015-A4, T2015-A5, T2015-A6) (Table 2, (Kjær et al., 2021b)).

10 At the EastGRIP site (T2015-A4 and T2015-A5) our results are comparable with previous estimates by Vallelonga et al. 2014; Kjær et al. 2016a; Du et al. 2019. At the NEEM site (T2015-A1) the observed calcium is comparable yet in the lower estimate of that found in the Holocene for the NEEM deep ice core ( $\sim$ ppb, Schüpbach et al. 2018), whilst the ammonium is directly comparable to that of NEEM Holocene ( $\sim 5 \mathrm{ppb})$, suggesting no significant recent increases in these proxies compared to the remainder of the Holocene. This result is also concurrent with recent data from the NEEM site (1982-2011) of $5.5+-5.7 \mathrm{ppb}$

$15 \mathrm{NH}_{4}{ }^{+}$and $4.7+-4.7 \mathrm{ppb} \mathrm{Ca}^{2+}$ (Gfeller et al., 2014).

Gfeller et al. 2014 investigated several shallow cores at the NEEM site and reported that annual deposited aerosol concentrations in shallow firn cores can vary strongly over distances of a few meters. The study pointed out that one drill site could be representative for $>60 \%$ of the variability within a squared area of $100 \mathrm{~m}^{2}$. We add that in Northern central Greenland for distances $>100$ kilometres apart significant mean concentration changes between sites is not resolved beyond noise for

20 insoluble dust (counts $\mathrm{ml}^{-1}$ ), $\mathrm{Ca}^{2+}$, nor $\mathrm{NH}_{4}{ }^{+}$.

This suggest that the dust and ammonium are mainly wet deposited in central Northern Greenland, producing similar concentration across all sites and suggest a single source area for each species far enough distant that individual weather events are not influencing the signal. 
https://doi.org/10.5194/cp-2021-99

Preprint. Discussion started: 16 August 2021

(c) Author(s) 2021. CC BY 4.0 License.

(c) (i)

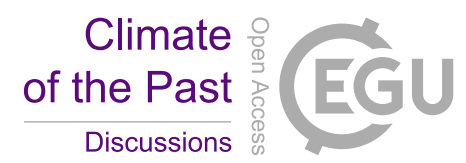

We observe a clear spatial variability for hydrogen peroxide with $\mathrm{H}_{2} \mathrm{O}_{2}$ concentrations in the northwest (96-110 ppb) twice that in central and northeast Greenland (39-49 ppb) owing to the photolysis re-activation loss at the lower accumulation sites (Sigg and Neftel, 1988; Frey et al., 2006).

5 The conductivity also shows variation between sites and decreases from close to $2 \mu \mathrm{S} \mathrm{cm}^{-1}$ in the low accumulation north-east (T2015-A4 and T2015-A5) to a $1.65 \mu \mathrm{S} \mathrm{cm}^{-1}$ at the higher accumulation sites west of the Greenland ice-divide (T2015-A1, T2015-A2, T2015-A3, Table 2 and supplementary figure S2). We suggest this is an effect of an increase in the total dry deposited ions (e.g. sea salts) being more dilute in the west, but speculate that it could also originate from an anthropogenic (North American) input reaching first the western central ice sheet and only later when more dispersed the eastern.

10 Unfortunately, the noise in the acid records from the 6 firn cores is too large to help resolve if anthropogenic changes is the source and sodium were not analyzed for these cores.

\section{Seasonal cycles}

The seasonal cycles by formal month are presented in Figure 3. As peroxide was used as the main cycle to date these cores we refrain from discussing its seasonal cycle. Still, we do note that for all sites except T2015-A6 the seasonal cycles of $\mathrm{H}_{2} \mathrm{O}_{2}$ is

15 sinusoidal with the confidence intervals distributed almost equally above and below, where the maximum peak is defined as summer solstice (June), and the minimum is observed in the formal months December and January. However, for the low accumulation site (T2015-A6) it is evident that dating using just $\mathrm{H}_{2} \mathrm{O}_{2}$ was challenging and that the use of $\mathrm{Ca}^{2+}$ have shifted the peak value towards 2 months late (to $\sim$ August) and made the $\mathrm{H}_{2} \mathrm{O}_{2}$ seasonal cycle look less sinusoidal than seen at the other sites. This uncertainty on the dating is likely reflected in the seasonal cycle for other proxies in the T2015-A6 traverse core, and thus care should be taken interpreting especially the T2015-A6 seasonal cycles. 
https://doi.org/10.5194/cp-2021-99

Climate

Preprint. Discussion started: 16 August 2021

(c) Author(s) 2021. CC BY 4.0 License.

(c) (i)
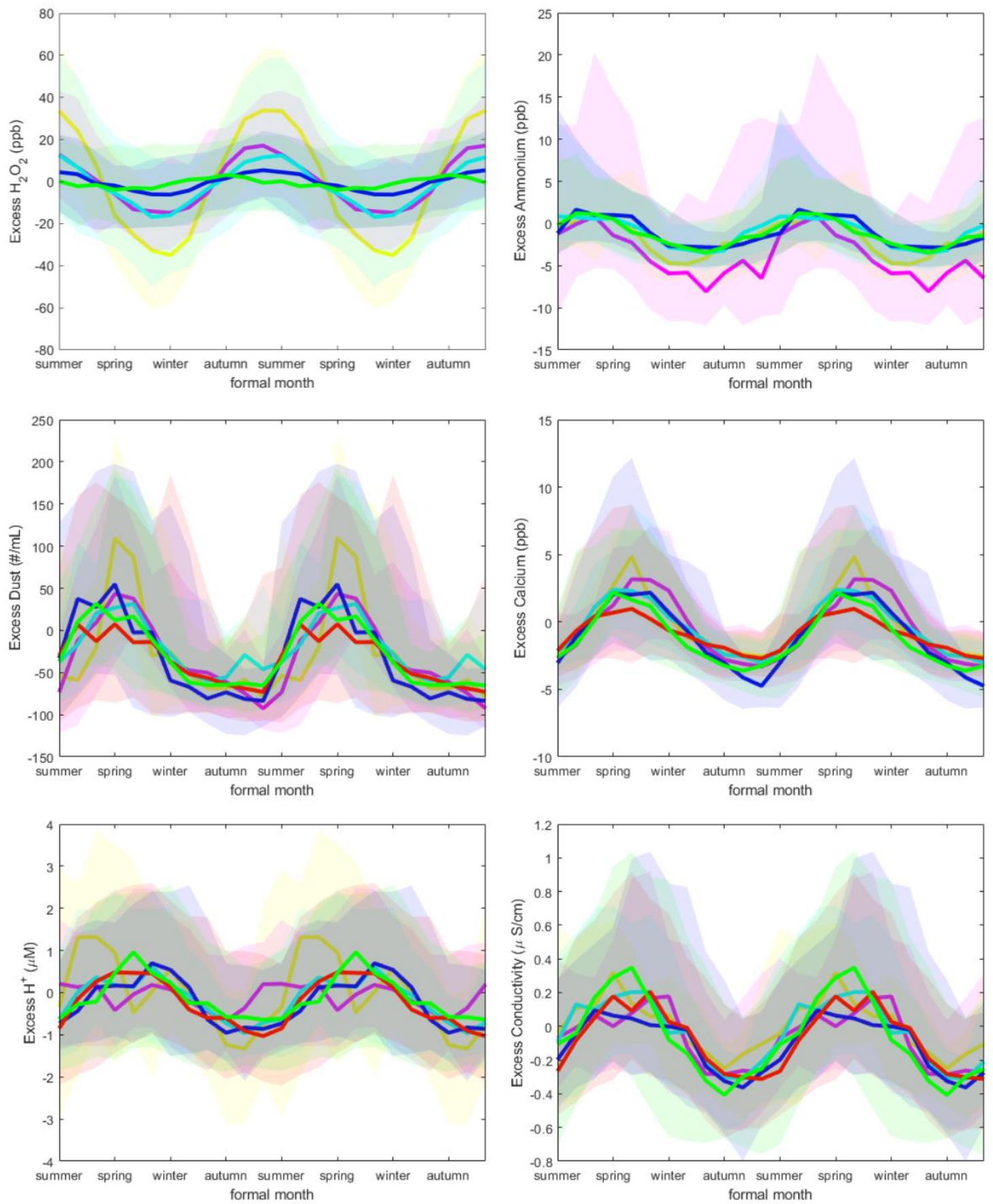

Figure 3: Average seasonality. From top left is shown $\mathrm{H}_{2} \mathrm{O}_{2}, \mathrm{NH}_{4}^{+}$, Insoluble dust, $\mathrm{Ca}^{2+}, \mathrm{H}^{+}$and Conductivity. The colors reflect cores T2015-A1 (yellow), T2015-A2 (purple), T2015-A3 (cyan), T2015-A4 (blue), T2015-A5 (red) and T2015-A6 (green). Shaded area indicate the variability of the seasonality for each core, characterized by $16 \%$ to $84 \%$ quartiles of monthly averaged records. 


\subsection{Summer biosphere activity in Ammonium}

$\mathrm{NH}_{4}{ }^{+}$has a distinct peak in the late spring and early summer months (April-June) catching the highest biological activity, while minimum concentrations occur in a wider part of the year from late autumn and early winter (Oct-Dec). The variability is high and unevenly distributed as a result of high summer peaks suggested to be caused by forest fires, which may bias the monthly

5 mean value by a shifting seasonality. Gfeller et al. 2014 suggested mean ammonium to peak in formal months June/July and that the peak had shifted from preindustrial when it was as late as July/August for the NEEM site. We attribute the discrepancy to the uncertainty associated with the formal month definition and in differences in dating strategy, as we also note that the $\mathrm{H}_{2} \mathrm{O}_{2}$ seasonal cycle observed by Gfeller et al. 2014 are shifted by 2 months compared to our assignment of peak $\mathrm{H}_{2} \mathrm{O}_{2}$ in summer solstice.

\section{$10 \quad 4.2$ Winter storms carry dust inland}

Insoluble dust particles and $\mathrm{Ca}^{2+}$ as its soluble compound, coming from e.g. $\mathrm{CaCO}_{3}$, or $\mathrm{CaSO}_{4}$, are common paleo-climatological proxies for global aridity and wind strength. The seasonal cycles in the traverse cores show a late winter/early spring peak (Calcium Jan-March, insoluble dust Feb-May) as also observed by others (Kang et al., 2015; Kuramoto et al., 2011; Amino et al., 2020). We observe high deviations in adjacent months. Minimum concentrations are found in the summer months July and

15 August. The calcium seasonal cycle is smooth compared to that of the insoluble dust and in the cores T2015-A4, T2015-A5 (EastGRIP site) and T2015-A6 (central divide) it looks like insoluble dust is deposited twice a year (early spring and late autumn/early winter). Whilst this may be due to a local source as was speculated in other areas of Greenland (Amino et al., 2020; Bullard and Mockford, 2018; Nagatsuka et al., 2021), it could also be ascribed the fact that deposition events are rare in north Central Greenland (McIlhattan et al., 2020) and thus the dust peak could be found in other formal months.

\section{4.3 Spring Arctic haze in acid and conductivity}

Maximum concentrations of acid are recorded in early spring (March), however with a wide distribution in the adjacent months (January-May). This is in line with previous findings where the spring acid peak in Greenland ice cores is attributed the modern Arctic haze phenomenon, with anthropogenic pollutants such as $\mathrm{SO}_{2}$ building up in the atmosphere during stable and dry winter conditions being deposited in spring, when precipitation rates grow (Gfeller et al., 2014; Kuramoto et al., 2011; Quinn

25 et al., 2007). As the conductivity is mainly driven by the $\mathrm{H}^{+}$(Kjær et al., 2016) it peaks in close proximity, however one month shifted towards an earlier deposition due to the influence likely from sea salts. Similar observations of seasonality have been made at the NEEM site (Jan-Apr); and Humboldt North sites (Dec-March) (Gfeller et al., 2014; Pasteris et al., 2012).

Finally, we note that high resolution records, as in this study resolves variability related not only to the seasonal cycles, but 30 also to instrument or site specific noise and this noise limits the records capability to resolve spatial variations between the firn records. Site specific noise is related to the local precipitation patterns, which can be disturbed by wind causing the formation 
of dunes, sastrugis or crust layers. These features mix up already deposited snow especially if precipitation is very event based, melt layers at sites experiencing higher temperatures and ablation can also redistribute the deposited ions in the snow pack (Laepple et al., 2016; Gfeller et al., 2014).

\section{Temporal trends}

5 In the following we investigate temporal trends observed in the six records. We find a clear signal of the 1970's acid contamination in the conductivity and increases in the intermediate and large insoluble dust fluxes suggesting an activated transport of local Greenland dust to the Northern Greenland Ice Sheet, more so at lower altitude sites closer to the coast.

\subsection{Anthropogenic increase in the 70's and 80's observed in the conductivity}

Since the 1970's a decrease in conductivity associated with reduced anthropogenic sulphur and $\mathrm{NO}_{\mathrm{x}}$ emissions has previously

10 been observed in firn records from Greenland (Fischer et al., 1998; Kjær et al., 2016; Pasteris et al., 2012). For our oldest records, T2015-A5 and T2015-A6, a decrease in the conductivity between the early part of the record (1960's-1990s) and the younger part confirms this (Figure 2 and supplementary Figure S2). The conductivity in polar ice cores is found to be mostly controlled by $\mathrm{H}^{+}$(Kjær et al., 2016). We would thus expect similar trends of anthropogenic contamination in the acid record. Unfortunately, the noise in the acid record is larger than the trend (Table 2). This is both a result of the measurement technique

15 being subject to flow sensitivity (Kjær et al., 2016), but also because individual peaks associated with volcanic events (section 6.1) are influencing the signal significantly.

\subsection{Local dust activation}

Recent publications have suggested that with warming and current mass loss in Greenland, local sources of dust are activated. For the Holocene large sized particles of local dust are observed in coastal ice core sites (Marius Folden Simonsen et al., 2019)

20 and at the SE-Dome core (South east Greenland) an increase in the local sourced dust flux in the period 2000-2010 compared to 1960-2010, shown as an increase in the larger particles (>5um) in the autumn was found (Amino et al., 2020). In the west (Kangerlussuaq) local dust activation in the period 2000-2010 have been observed (Bullard and Mockford 2018) and in the North-West ice core Sigma-D the period 1915-1949 and 2005-2013 had a mineral composition suggesting a west Greenland source, while the remainder of the past 100 yrs suggested a Canadian dust source area suggested related to warmer temperatures

25 in Greenland activating the local dust source areas (Nagatsuka et al., 2021).

When comparing the period between 2000 and 2015 to that of the full firn cores (Table 2) we do not observe any significant increase in the total number of insoluble particles at any of the 6 northern sites studied nor in the calcium concentrations (Figure 2).

The annual insoluble dust flux (Table 3, Figure S3) was determined assuming all spheres were perfectly round, using a mean 30 density of $2400 \mathrm{~kg} / \mathrm{m} 3$ of the dust and annual accumulation for the 6 sites (Kjær et al., 2021b). We note that uncertainty 
https://doi.org/10.5194/cp-2021-99

Preprint. Discussion started: 16 August 2021

(c) Author(s) 2021. CC BY 4.0 License.

(c) (i)

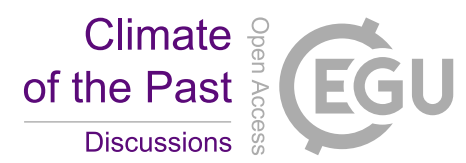

associated with the flux calculation is related to the accumulation and the assumption of spherical dust and that the following must not be over interpreted. We find a total dust flux between 0.016 and $0.062 \mathrm{mg} \mathrm{kg}^{-1} \mathrm{yr}^{-1}$ with the smaller fluxes at the central higher altitude sites (T2015-A3 and T2015-A6) as anticipated. We further split the data into three bins; small (1.25 to 2.9 um radii), intermediate ( 2.9 to $8.13 \mathrm{um}$ ) and large ( 8.13 to $10.5 \mathrm{um}$ ) (Simonsen et al., 2019). Thus omitting the largest and

5 smallest sizes. The largest sizes as they are subject to poor statistics and the smallest bins as they are noisy. We find that by parting this way we have $12-28 \%$ of the total dust in the small range, $43-53 \%$ in the intermediate range and in the large range just 6-13\% of the total insoluble dust flux observed in the cores over the period 1998-2015. For the central cores, T2015-A3 and T2015-A6, the large particle fluxes are just 3 to $6 \%$ suggesting that the large particles do not make it to the high central ice cap to the extent that it does the lower altitude sites.

10 In the following we investigate the trend in the dust flux over the period 1998-2015 (Table 3, Figure S3). First of all, we note that the record is noisy and that the p-values in what we discuss next are relatively high (significant $\mathrm{p}<0.1$ ). In all but the central core T2015-A6, we observe an increase in the total insoluble dust flux (ug kg-1 w.eq) of $2.4 \%$ to $4.6 \%$ a year, significant $(\mathrm{p}<0.10)$ for the cores T2015-A1, T2015-A2, T2015-A3 and T2015-A5. Excluding T2015-A6, we note that the small particle fluxes increase between $0.4 \%$ and $3.1 \%$ annually, only significantly though for T2015-A1 $(\mathrm{p}<0.1)$. Intermediate dust sizes increase every year by between 2.4 and 4.5\%, significantly for T2015-A1, T2015-A3 and T2015-A5 and the large bins increase by 2.3 to $4.8 \%$ annually for T2015-A1, T2015-A2, T2015-A4 and T2015-A5. This suggests that the increasing trend is mainly at the intermediate and large particle sizes, which we interpret to reflect an increased activation of local dust in northern Greenland over the period 1998-2015. We further note that the trend in large particles is strongest in T2015-A1, T2015-A4 and T2015-A5, which are lower in altitude and closer to the coastal local dust.

Table 3: Dust fluxes and trends in dust fluxes for the period 1998-2015 for each of the 6 shallow firn cores. Small (1.25-2.9 $\mu \mathrm{m})$, intermediate $(2.9-8.13 \mu \mathrm{m})$ and large $(8.13-10.5 \mu \mathrm{m})$ refers to the dust sizes as analyzed by the Abakus instrument. When significant $\mathrm{p}<0.05$ just in bold and when $\mathrm{p}<0.1$ in italic. 


\begin{tabular}{|c|c|c|c|c|c|c|c|c|}
\hline \multirow[b]{2}{*}{$\begin{array}{l}\text { Firn } \\
\text { core }\end{array}$} & \multicolumn{4}{|c|}{$\begin{array}{l}\text { Dust Flux } \\
{[\mathrm{mg} / \mathrm{kg} / \mathrm{yr}]}\end{array}$} & \multicolumn{4}{|c|}{$\begin{array}{l}\text { Dust flux trend }[\mathbf{m g} / \mathbf{k g} / \mathbf{y r} 2] \\
\text { (p-value) }\end{array}$} \\
\hline & Total & Small & Intermed & Large & Total & Small & Intermed & Large \\
\hline $\begin{array}{l}\text { T2015- } \\
\text { A1 }\end{array}$ & 62.34 & 7.57 & 28.28 & 8.23 & $\begin{array}{r}2.89 \\
(0.026)\end{array}$ & $\begin{array}{r}0.24 \\
(0.075)\end{array}$ & $\begin{array}{r}1.29 \\
(0.041)\end{array}$ & $\begin{array}{r}\mathbf{0 . 3 7} \\
(\mathbf{0 . 0 5 0})\end{array}$ \\
\hline $\begin{array}{l}\text { T2015- } \\
\text { A2 }\end{array}$ & 40.56 & 6.31 & 18.10 & 4.37 & $\begin{array}{r}0.96 \\
(0.100)\end{array}$ & $\begin{array}{r}0.11 \\
(0.288)\end{array}$ & $\begin{array}{r}0.44 \\
(0.208)\end{array}$ & $\begin{array}{r}0.16 \\
(0.059)\end{array}$ \\
\hline $\begin{array}{l}\text { T2015- } \\
\text { A3 }\end{array}$ & 19.32 & 4.81 & 10.22 & 1.07 & $\begin{array}{r}0.48 \\
(0.075)\end{array}$ & $\begin{array}{r}0.11 \\
(0.186)\end{array}$ & $\begin{array}{r}0.34 \\
(0.041)\end{array}$ & $\begin{array}{r}0.02 \\
(0.292)\end{array}$ \\
\hline $\begin{array}{l}\text { T2015- } \\
\text { A4 }\end{array}$ & 47.25 & 8.67 & 21.63 & 4.68 & $\begin{array}{r}1.20 \\
(0.185)\end{array}$ & $\begin{array}{r}0.03 \\
(0.850)\end{array}$ & $\begin{array}{r}0.74 \\
(0.109)\end{array}$ & $\begin{array}{r}0.20 \\
(0.071)\end{array}$ \\
\hline $\begin{array}{l}\text { T2015- } \\
\text { A5 }\end{array}$ & 58.00 & 8.42 & 24.86 & 7.15 & $\begin{array}{r}2.00 \\
(0.070)\end{array}$ & $\begin{array}{r}0.11 \\
(0.511)\end{array}$ & $\begin{array}{r}0.76 \\
(0.100)\end{array}$ & $\begin{array}{r}0.34 \\
(0.072)\end{array}$ \\
\hline $\begin{array}{l}\text { T2015- } \\
\text { A6 }\end{array}$ & 16.16 & 4.58 & 8.30 & 0.48 & $\begin{array}{r}-0.09 \\
(0.740)\end{array}$ & $\begin{array}{r}-0.05 \\
(0.562)\end{array}$ & $\begin{array}{r}0.03 \\
(0.863)\end{array}$ & $\begin{array}{r}0.01 \\
(0.366)\end{array}$ \\
\hline
\end{tabular}

\section{Extreme events}


https://doi.org/10.5194/cp-2021-99

Preprint. Discussion started: 16 August 2021

(c) Author(s) 2021. CC BY 4.0 License.

In the following we investigate the extreme events (>0.97 quantile) observed in conductivity, acid and ammonium after removing a five year running median.

6.1 Spatial distribution of recent Volcanic events- excess acid and conductivity.

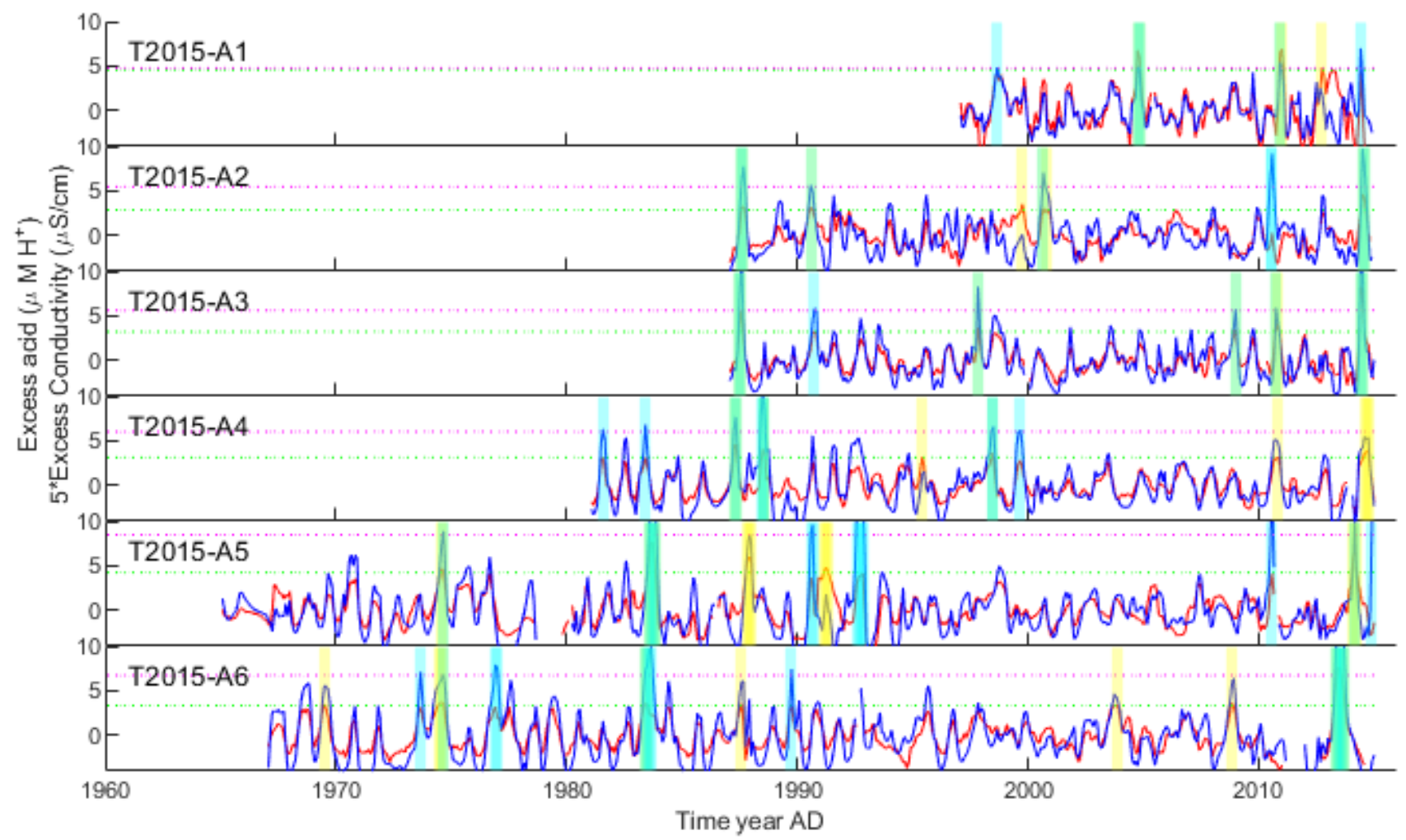

$5 \quad$ Figure 4: Excess acid (red) and Excess conductivity (blue) as compared to a 5 year running average. Note that the conductivity is scaled with a factor 5. Dashed horizontal lines indicate $97.5 \%$ quantile for conductivity (green) and acid (). Vertical bars indicate times exceeding 2 standard deviations for conductivity and acid compared to a 5 year running average in yellow and cyan respectively, green when observed in both. From top is shown T2015-A1 through to T2015-A6 in the bottom.

Peaks exceeding the background observed in acid or in conductivity in ice cores are often interpreted as volcanic eruptions

10 and used for constraining ice core ages (Sigl et al., 2016; Svensson et al., 2008; Vallelonga et al., 2014; Kjær et al., 2016). In addition, such acid markers can be used to determine volcanic climate forcing from volcanic eruptions used in climate modelling (Gao, Robock, and Ammann 2008; Robock and Free 1995). In Figure 4 extremes in the acid/conductivity determined by peaks exceeding $97.5 \%$ quantiles from the $5 \mathrm{yr}$ running average based on monthly means are shown and interpreted as volcanic horizons. Vertical bars in green, yellow and turquoise show which eruptions were identified in conductivity, acid or both proxies respectively for each of the 6 firn cores, thus providing an overview of the spatial distribution in northern Greenland of specific acid plumes. Already from a first look it is evident that not all plumes distribute to the entire northern Greenland and thus we confirm the previous findings (Robock and Free 1995; Gao, Robock, and Ammann 2008) 
https://doi.org/10.5194/cp-2021-99

Preprint. Discussion started: 16 August 2021

(c) Author(s) 2021. CC BY 4.0 License.

\section{(c) (i)}

that a single core can't be used if aiming to create a record of volcanism from ice cores. Further using the conductivity alone can be deceiving if aiming to find volcanic horizons. We also emphasize our dating was restricted to use mainly $\mathrm{H}_{2} \mathrm{O}_{2}$ and $\mathrm{Ca}^{2+}$, and thus we have not made any volcanic matching between the records as part of the dating.

The eruptions that are observed in more than one of our traverse cores are; Bardabunga 2015 (all), Grimsvotn 2011 (all, but

5 T2015-A6), Grimsvotn 1998 (T2015-A1, T2015-A3, T2015-A4, T2015-A5), Pinatubo 1991 (T2015-A2, T2015-A3 and T2015-A5), Redoubt 1989 (T2015-A2, T2015-A3 and T2015-A5), unknown 1987 (T2015-A2, T2015-A3,T2015-A4), unknown 1974 (T2015-A5 and T2015-A6). Below we discuss the sources for the acid and conductivity reference horizons observed in the firn cores in more detail.

In late august 2014 until February 2015 the Bardarbunga fissure, also known as the Holuhraun eruption (Volcanic eruption

10 index -VEI 0) took place in Iceland. The SO2 emissions are estimated to have been 10.7 $\pm 3.0 \mathrm{Mt}$ (S.R. Gíslason et al., 2015). We observe elevated acid in all of our firn cores of between 4.3 to $12.1 \mathrm{uM} \mathrm{H}^{+}$, but note that T2015-A6 is offset compared to the other records due to uncertainty in the depth registration of the top. T2015-A3, T2015-A6 and T2015-A5 show the highest acid concentrations from the Holuhraun eruption while T2015-A2, T2015-A4 and T2015-A1 are less pronounced. At the EastGRIP site previous results from snow pits also evidence the eruption (Du et al., 2019). The fact that this eruption is found

15 at all 6 sites and also in various other north Greenland sites (Kjær et al., 2021a) suggest that this eruption horizon is deposited in the wider Central Northern Greenland. Despite the modelled $\mathrm{SO}_{2}$ and $\mathrm{SO}_{4}$ plume trajectories from the eruption by e.g. (Boichu et al., 2019) not reaching Greenland.

Another peak (6.7-8.6 uM) observed through most the firn cores, except T2015-A6 central Greenland core, is the Grimsvötn 2011 (VEI4), Iceland. The eruption took place from 21-28 ${ }^{\text {th }}$ of May 2011(Hreinsdóttir et al., 2014) and had major societal

20 impact as 900 flights were cancelled in Europe, despite the fact that the plume of particles stayed mostly local and turned northward. Modelling suggests that the particles travelled mostly westward reaching as far as Finland, while the sulphuric acid moved at a higher level northward toward Greenland, where it turned westward crossing over Greenland. The traverse records evidence that acid from the Grimsvötn eruption was deposited even further north than found in the modelled plumes (Moxnes et al., 2014; Kerminen et al., 2011; Petersen et al., 2011).

25 The famous Eyjafjallajökull eruption (VEI4) between 14 April-23 May 2010 is not strong enough to enhance the acid above background variability. This is expected as the plume from this eruption had a south-eastward track down over Europe (Schumann et al., 2011; Thomas and Prata, 2011), and only after a major turnaround towards the northern globe the acid reached the North west Greenland. Some weak evidence can be seen in the 3 traverse cores west of the divide.

Grimsvötn 1998 (VEI2) extended for 10 days long in December with a plume up to $10 \mathrm{~km}$ altitude. An increase in acid as high

30 as 7.6-9.0 $\mu \mathrm{M} \mathrm{H}^{+}$is observed in the firn cores in late 1998 and early 1999, suggesting that the plume from the eruption made it to the northern central Greenland. The peak is only high enough to exceed the 97.5\% quantile in T2015-A1 and T2015-A4, but is also clearly evidenced in T2015-A2, T2015-A3 and T2015-A5 as an elevated acid concentration for a longer period. The Pinatubo 1991 eruption (VEI6, June), which has previously been reported both at the Greenland NEEM site and the Antarctic WAIS site (Sigl et al., 2016) is only observed in the T2015-A2, T2015-A3 and T2015-A5 and thus its use as a 
https://doi.org/10.5194/cp-2021-99

Preprint. Discussion started: 16 August 2021

(c) Author(s) 2021. CC BY 4.0 License.

\section{(c) (i)}

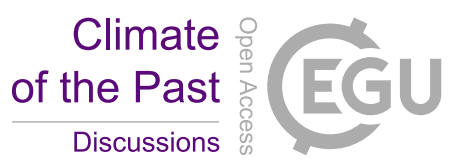

synchronisation event between hemispheres might be limited as it does not show in all our Greenland cores. We also note that Pinatubo was not significantly found in the NEGIS record (Vallelonga et al., 2014) close to our T2015-A5 and T2015-A4 records. Further, we recall that a small eruption from the Icelandic Hekla took place in 1991 (0.02 km3 tephra (Thordarson and Larsen, 2007)) and suggest that as an alternative source of what is observed in Greenland cores in 1991.

5 The Redoubt eruption 1989 (VEI3) in southern central Alaska consisted of more than 20 individual eruption events that began in December 14 1989 and lasted until late 1990 (Casadevall, 1994; Scott and McGimsey, 1994). During the eruption sulfur dioxide emission rates were between 800-6600 metric tonnes a day, with the highest emissions in March and tephra plumes are documented to altitudes of 7-10 km (Brantley, 1990; Scott and McGimsey, 1994). We observe an imprint in T2015-A2, T2015-A3 and T2015-A5 of what could be the Redoubt eruption, with acid concentrations of 8.7-10.3 $\mu \mathrm{M} \mathrm{H}^{+}$.

10 The Cleveland, Aleutian Iceland eruption (VEI3) took place in late 1987 and lasted for about 2 months and a signature is distributed through all our records in 1987. However, we note that Cleveland is an active volcano with at least 22 eruptions over the past 230 years and other VEI 3 eruptions from Cleveland happened in 1994, 2001, 2006, with multiple smaller eruptions in between. We note that in T2015-A2 a peak exceeding 97.5\% is observed also in 2001. In T2015-A1 and T2015A2 acid is also elevated in 2006 though not exceeding 97.5\%. We wonder about the lack of signal in the other firn cores from

15 these large eruptions from Cleveland and speculate that the source in 1987 may not be Cleveland. Other sources of large volcanic eruptions in the period 1986-1987 include Mount Augustine 1986, Alaska (VEI 4), which also erupted in 2005/2006 (VEI3) and the Russian eruptions of Chikurachki-Kuril Islands and Kliuchevskoi-Kamchatka in 1986 (VEI 4) and 1986 Nov (VEI 4) respectively. We note the latter having also erupted in 1985/1986, 1980 and 1974 of VEI3 size and a smaller in $1965 / 66$.

20 In May 1983 a plume of $10 \mathrm{kt} \mathrm{SO}_{2}$ rose up to $8 \mathrm{~km}$ from the Grimsvötn volcano, and in all cores covering that period we observe a significant peak in acid concentrations for that year, again suggesting a central Greenland route. Yet, this eruption only lasted 2 days. Another explanation for a 1983 peak in Greenland ice sometimes invoked is the spring VEI 5 Mexican El Chicon 1982 eruption (Palais et al., 1992).

When looking further back in our records, we note that one has to be careful when assigning excess acid to volcanic events as the period 1970-1980's is highly influenced by anthropogenic sulphates. Thus even after removing the mean background signal, spring Arctic haze events can be very high in sulphates and resemble volcanic strata. Regardless, we note the peaks that are found between the T2015-A5 and T2015-A6 sites reaching furthest back in time, and compare with the nearby NEGIS (Kjær et al., 2013, 2016; Vallelonga et al., 2014) and Humboldt North records (Pasteris et al., 2012).

The so-called Krafla Fires which consists of 9 individual eruptions took place in Iceland between 1975 and 1984 (Thordarson 30 and Larsen, 2007). We do not clearly observe the Krafla Fires in the records of T2015-A5. However, T2015-A6 shows a peak in late 1977 and we note that four rifting events occurred in the period 1976 Oct as part of the Krafla fires, with the last one in September 1977, which included an explosive event through a geothermal borehole producing $26 \mathrm{~m} 3$ of tephra (Thordarson and Larsen, 2007). In 1980's similar rifting occurred, but they are not mirrored in our Greenland records. We also note that Kjær et al. 2013 observed an increase in the conductivity for the NEGIS core in 1977 and similarly was observed at the 
Humboldt North site (Pasteris et al., 2012), suggesting that the plume took a route over central north-east Greenland. We note the last eruption of the Krafla fires was September 1984 and it may have contributed to the peak assigned to Grimsvötn above. We observe excess acid in 1974 for both T2015-A5 and T2015-A6 sites confirmed also at the Humboldt North site (Pasteris et al., 2012). We suggest it could be the VEI 3 from the Russian Kliuchevskoi-Kamchatka.

5 In 1971 we find in what potentially is the Hekla 1970 eruption signal of 0.07 tephra km3 0.03 tephra DRE km3 (Thordarson and Larsen, 2007), although we note that it is not large enough to exceed the 97.5\% boundary in T2015-A5 and it is not reflected in T2015-A6. However both in the NEGIS core close by T2015-A5 and in the Humboldt North core an increase in conductivity and acid is observed in 1970's (Pasteris et al., 2012; Kjær et al., 2016; Vallelonga et al., 2014).

In conclusion we find several recent horizons that can be attributed mainly to Icelandic volcanoes, but we note that many years

10 have a corresponding large (>VEI3) eruption in the regions of the Bering Sea region (Russian and Canadian Arctic) and thus the direct assigning of specific volcanoes is not straightforward when based solely on the excess acid or conductivity. Some of the significant acid and conductivity horizons observed across the 6 traverse cores are also seen in Humboldt North and NEGIS ice cores (Kjær et al., 2013, 2016; Pasteris et al., 2012; Vallelonga et al., 2014). We find that the modelled plumes for recent eruptions often do not reach the sites in which we find the acid deposited and suggest that such dispersion model long term transport could be improved.

\subsection{Canadian burned land area observed in extreme ammonium events}

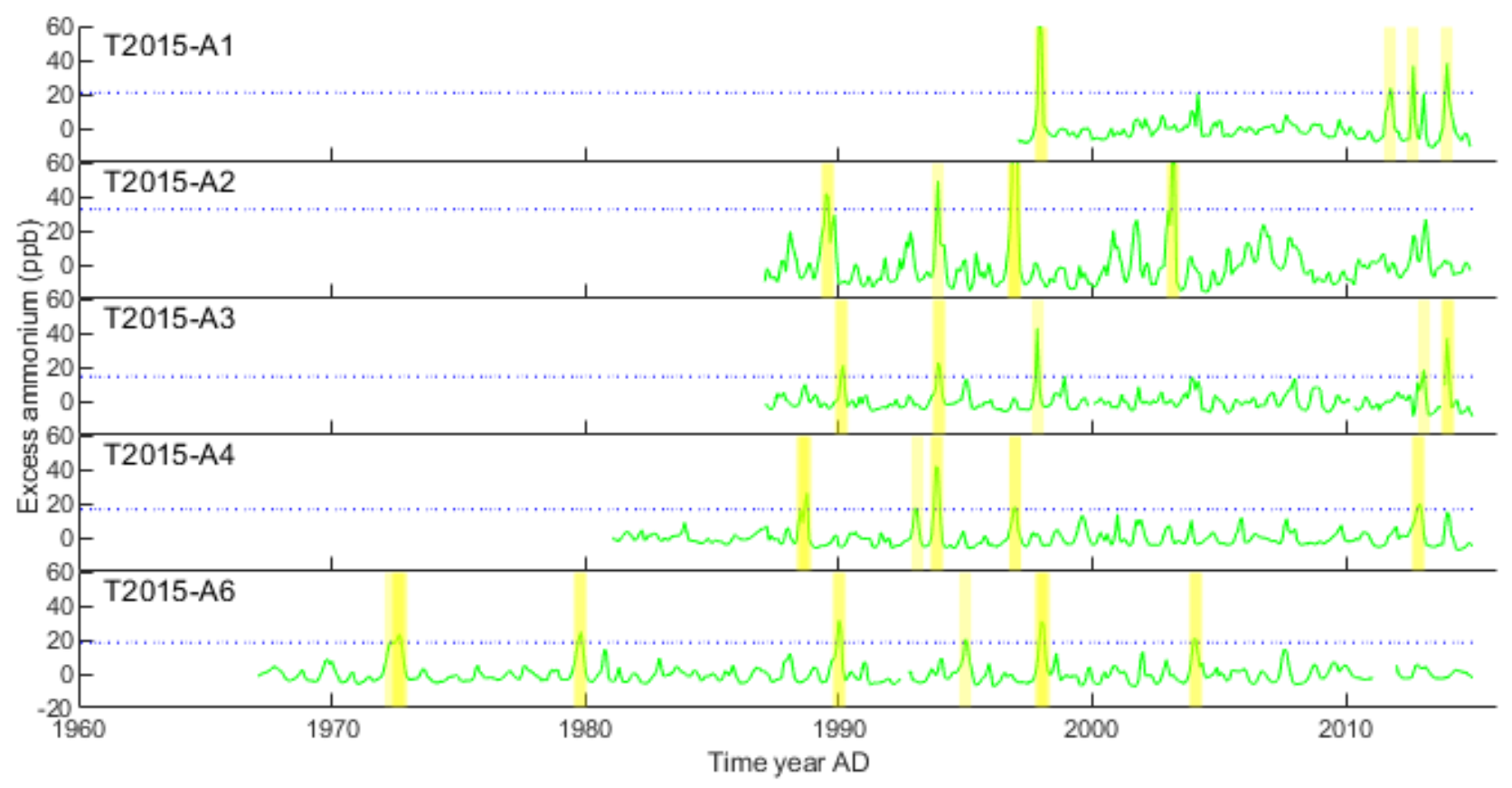


https://doi.org/10.5194/cp-2021-99

Preprint. Discussion started: 16 August 2021

(c) Author(s) 2021. CC BY 4.0 License.

\section{(c) (i)}

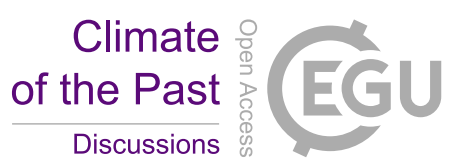

Figure 5: Excess ammonium (green) as compared to a 5 year running average. Vertical bars (yellow) indicate times exceeding the $97.5 \%$ quantile (horizontal blue dashed). From top is shown T2015-A1 through to T2015-A6 in the bottom, note T2015A5 was not analysed for ammonium.

5 The number and extent of fires through time of both natural and anthropogenic origin have varied and several fire index records exist. Extreme peaks in $\mathrm{NH}_{4}{ }^{+}$in ice cores have been used as a proxy for North American forest fires (Legrand et al., 1992; Zennaro et al., 2014; Fuhrer et al., 1996) while the background $\mathrm{NH}_{4}{ }^{+}$is related to biogenic emissions from soil and vegetation and thus temperature on a longer timescale. Other commonly used fire proxies in ice cores include formate, which is found well correlated with excess ammonium (Legrand et al., 1995; Savarino and Legrand, 1998), levoglucosan, which is specific to

10 biomass burning events, black carbon, which is also subject to other anthropogenic sources (Zennaro et al., 2014; Segato et al., 2021), dehydroabietic acid (Parvin et al., 2019) and vanillic acid (Grieman et al., 2018a; Kawamura et al., 2012; Grieman et al., 2018b). The amount of fires as determined in ice cores have been found to vary over time with an increase in the mid1600s (Zennaro et al., 2014) and it is speculated that current climate change and anthropogenic activity could enhance fires.

Here we assess excess ammonium (exceeding 97.5\%) as a proxy for forest fires in the 5 traverse cores (Figure 5, note T2015-

15 A5 was not analysed for $\mathrm{NH}_{4}^{+}$) and compare with fire records from other recent ice cores (Parvin et al., 2019; Zennaro et al., 2014; Gfeller et al., 2014; Legrand et al., 2016; Pokhrel et al., 2020). We use ammonium excess as a proxy for forest fires, however, bear in mind that ammonium is found to only replicate 8 out of 14 levoglucosan peaks at the NEEM site (Zennaro et al., 2014). Furthermore, for the NEEM site, Gfeller et al. 2014 observed that as a result of wind reworking, a single core close by 5 other cores only captures 70 to $80 \%$ of the interannual variability of the reconstructed ammonium atmospheric

20 aerosol load.

We start out by noting that the excess ammonium (after removing the 5 year running average) from the individual traverse records correlate well $(\mathrm{R}>0.4$, Table $\mathrm{S} 4)$ to each other in the central and west, if allowing for 1 year dating uncertainty for the records. West of the ice divide annual correlations are as high as 0.67 , while correlations between the western cores and the T2015-A6 central core is lower. T2015-A4 east of the divide is poorly correlated to the other records, but we note that the volcanic peaks seem to match well, suggesting that the dating is reasonably accurate between sites. We continue to make a combined fire proxy record for the 5 cores by normalizing for each of the records the annual excess peak value and taking the mean of the cores covering the years. We observe that the combined fire proxy record correlates with the Canadian National Forestry Database records of Forest burned area (Parisien et al., 2012; Canadian Forest Service, 2013) by R=0.51 ( $p=2.51 \mathrm{e}-$ 04) from 1987 onwards and for the period 1959-2015 $\mathrm{R}=0.44(\mathrm{p}=0.02)$. This suggests that the combined traverse record of 30 excess ammonium is a fair proxy of burned area in Canada (Figure 6). Omitting T2015-A4, the only eastern core we find that the central and western correlate with the Canadian forest fire record by 0.41 ( $\mathrm{p}=0.004,1987$ onwards), suggesting that adding even the eastern records improve the fire proxy. Further noting that the dating allows the records to be shifted, we tried shifting 
A2 and A4 to be one year younger, to better match the peak in 1998 and thus improve the combined proxy, however that was not the case (R-0.48, p10^-4, 1987-2015).

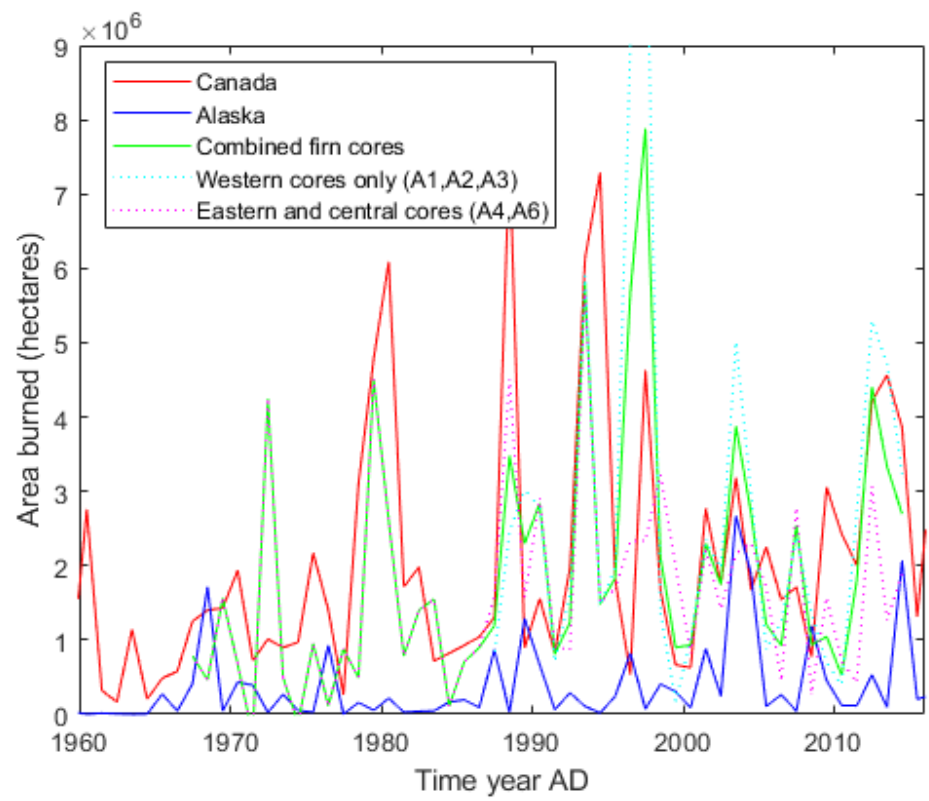

Figure 6 Forest fire composite compared to Canadian (Parisien et al., 2012; Canadian Forest Service, 2013) and Alaskan forest fire indexes (AICC - Predictive Services - Intelligence / Reports, 2021; Legrand et al., 2016).

5 We observe extreme ammonium (>97.5\% of full record) in the years 1973 (T2015-A6), 1980 (T2015-A6), 1988-1990 (T2015A2, T2015-A3, T2015-A4,T2015-A6), 1994 (T2015-A2, T2015-A3, T2015-A4, T2015-A6), 1997-1998 (T2015-A1, T2015A2, T2015-A3, T2015-A4, T2015-A6), 2004 (T2015-A2, T2015-A4), 2013-2014 (T2015-A1, T2015-A3, T2015-A4). Below we discuss the individual years of high ammonium concentration in comparison with other ice core records starting from the oldest peaks. We also speculate on sources and compare with Alaskan (AICC - Predictive Services - Intelligence / Reports, 10 2021) and Canadian fire indexes (Canadian Forest Service, 2013).

The peak in 1973 (T2015-A6) was also observed in the Kamchatka ice core (1972) and NEEM ice cores (1973), but not in southern D4 nor the central Summit cores (Zennaro et al., 2014; Kawamura et al., 2012; Legrand et al., 2016) and it is speculated to originate from Russian fires resulting from droughts in 1972.

The 1980-1981 events have previously been observed in the ammonium record around NEEM (S1 and main core) and in the

15 Northern Greenland Tunu vanillic acid record (Grieman et al., 2018b; Gfeller et al., 2014). The signal is also observed in our core T2015-A6 close to the ice divide, showing that the signal of the Canadian fires in 1980 ( $<4.5$ Mha) and 1981 ( $<6$ Mha) is widespread in Northern Greenland, and not wider Greenland as it is neither observed in the D4 nor the central Summit cores (Legrand et al., 2016).

The pattern of three peaks between 1989 and 2000's is observed in all records covering the period (T2015-A2, T2015-A3, 20 T2015-A4, T2015-A6). The same pattern was observed in the South Eastern SE-Dome core (Dehydroabietic acid, and low 
levoglucosan). The pattern is repeated also at the NEEM site provided the dating uncertainty of $+/-1$ year is taken into account (Gfeller et al., 2014). In addition the peaks around 1994 was also observed at Summit station with an increase in ammonium and formate (Legrand et al., 2016) making the 1994 signal Greenland wide (Parvin et al., 2019), while 1990's peak is not. In the Canadian burned area record 1989 (>7.5Mha), both 1994 and 1995 (>6Mha) and 1998 (4.5Mha) are significant, making

5 Canadian fires the likely source areas for the events observed in the traverse records in the 90's.

2005 is less significant in the Canadian burned area record ( 3 Mha), but we note that note that the Alaskan Taylor Complex (2.4 Mha) fire, which is the largest in Alaskan records since 1940, might also add to the signal observed in central north Greenland (T2015-A2 and T2015-A6). In 2005 elevated Levoglucosan was also found in an Alaskan ice core (Pokhrel et al., 2020) and ammonium have previously been observed around NEEM (Gfeller et al., 2014), and in the SE-dome ice core

10 Dehydroabietic acid is elevated, suggesting that the $2005 \mathrm{NH}_{4}{ }^{+}$deposition is widely spread over Greenland, despite not being observed in all the firn cores presented here.

In 2013, 2014 and 2015 the Canadian record of burned area is about 4Mha annually. Thus Canadian forest fires is a candidate for the three elevated peaks at T2015-A1 (Neem site), as also observed in 2014 and 2015 at the T2015-A3 and T2015-A4 sites. Elevated fire tracers (levoglucosan and dehydroabietic acid) are also observed at the SE-Dome ice core in South Eastern

15 Greenland in the same years, suggesting the signal is dispersed Greenland wide (Parvin et al., 2019).

In conclusion we find several peaks of excess (>97.5\%) ammonium (Figure 5) in the 6 traverse cores. However not all ammonium peaks are observed in each record and despite careful dating, the peaks between records are in some cases shifted by one year, confirming that one site alone is not enough to reconstruct a precise fire record of the past. The ammonium peaks that exist through the 6 firn records are also observed in other ice core records from Greenland (NEEM, SE-dome or Summit

20 sites) suggesting that they are fires large enough to impact a large part of the Northern hemisphere. Furthermore, we find a good correlation between our records and Canadian fire records (0.44), suggesting that longer records of ammonium from Northern Greenland, such as those from the NEEM and EastGRIP sites, can be used as a proxy for Canadian forest fires in recent times.

\section{Conclusion}

25 Limited sources are available on the chemical impurities deposited to the northern part of the Greenland ice sheet in recent time (e.g. Gfeller et al., 2014; Hawley et al., 2014; Vallelonga et al., 2014; Kjær et al., 2021a). We add six additional chemical proxy profiles to the large north Greenland interior in a resolution that dissolves seasonal signals. The cores T2015-A2, T2015A3 and T2015-A6 offer a first view on the total amount and seasonal cycles of impurities deposited to their specific central north locations. The core T2015-A1 adds to the array of cores previously drilled at the NEEM site, whilst T2015-A4 and

30 T2015-A5 update the NEGIS core previously drilled close by at the East Greenland ice stream.

We observe a spatial variability in conductivity and peroxide concentration related to accumulation, while for dust (insoluble and calcium) and ammonium we do not observe significant changes in concentration between sites. 
We observe similar seasonal cycles as those previously reported by others in northern Greenland, but find that our formal month definition defined mainly by $\mathrm{H}_{2} \mathrm{O}_{2}$ summer peaks shifts the peak deposition by up to two months compared to that found by others defining summer by a mixture of proxies. We attribute this in part to the accumulation being non evenly distributed through the year. We highlight thus the importance of using same methods for constraining and dividing the year into months

5 when aiming to investigate changes in seasonality.

We observe temporal trends in the acid/conductivity related to the 1970's anthropogenic contamination of the atmosphere. In the dust fluxes we observe an increase, especially in large (8.15-10 um) and intermediate particles (2.19-8.15 um), which could be associated with the downward trend in accumulation for the period 2000-2010 observed by Kjær et al. (2021) or interpreted as a sign of increased local dust in the period, as found previously by Nagatsuka et al., 2021 in the North-west, Amino et al.,

102020 in a southern coastal site and by Bullard and Mockford (2018) at the west coast. Thus adding to the evidence of local dust transport in Greenland.

By stacking the normalized ammonium excess records from northern Greenland we find a good correlation with Canadian forest fires (0.44) suggesting it can be used as a proxy for specifically Canadian forest fires, more so than the individual records of ammonium.

15 We also find several recent volcanic eruptions shown in the cores as layers in the detrended acid and conductivity exceeding 97.5\%. We find Icelandic sources for most, but note volcanic activity at the Barents Sea region could be a source for some events. Some of the assigned volcanic horizons has North Greenland interior wide deposition signals that can be used to temporally constrain future firn and ice records and may further be useful for radar tracking of recent accumulation.

Despite each of the 6 firn records having value on its own it is clear that more extensive investigations are essential to reduce

20 spatial uncertainty, cancel out site specific noise and improve the representativeness of isolated locations. This is particularly true if we wish to further constrain the spatial variability in proxies used in ice core paleo research, as in these records such spatial variability is for some proxies (calcium, insoluble dust and ammonium) overwhelmed by the noise from surface topography and deposition.

\section{Data availability}

The data sets from the 6 firn cores; T2015-A1 to T 2015-A6; will be made available at www.Pangaea.de upon publication.

\section{Author contribution}

HK and PV collected the samples during the field season 2015. HK, PZ, PV, KHL, AS, SB analysed the firn cores by means

30 of CFA. HK and PZ made the annual layer counting and further interpreted the chemistry data. All authors contributed to the writing of the paper.

\section{Acknowledgements}


The research leading to these results has received funding from the European Research Council under the European Community's Seventh Framework Programme (FP7/2007-2013) / ERC grant agreement 610055 as part of the ice2ice project. This project has received funding from the European Union's Horizon 2020 research and innovation programme under grant agreement No 820970 as part of the TiPES project.

5 We acknowledge EGRIP and NEEM ice core drilling projects. EGRIP is directed and organized by the Center of Ice and Climate at the Niels Bohr Institute. It is supported by funding agencies and institutions in Denmark (A. P. Møller Foundation, University of Copenhagen), USA (US National Science Foundation, Office of Polar Programs), Germany (Alfred Wegener Institute, Helmholtz Centre for Polar and Marine Research), Japan (National Institute of Polar Research and Arctic Challenge for Sustainability), Norway (University of Bergen and Bergen Research Foundation), Switzerland (Swiss National Science

10 Foundation), France (French Polar Institute Paul-Emile Victor, Institute for Geosciences and Environmental research) and China (Chinese Academy of Sciences and Beijing Normal University). NEEM is directed and organized by the Center of Ice and Climate at the Niels Bohr Institute and US NSF, Office of Polar Programs. It is supported by funding agencies and institutions in Belgium (FNRS-CFB and FWO), Canada (NRCan/GSC), China (CAS), Denmark (FIST), France (IPEV, CNRS/INSU, CEA and ANR), Germany (AWI), Iceland (RannIs), Japan (NIPR), Korea (KOPRI), The

15 Netherlands (NWO/ALW), Sweden (VR), Switzerland (SNF), United Kingdom (NERC) and the USA (US NSF, Office of Polar Programs).

\section{References}

Amino, T., Iizuka, Y., Matoba, S., Shimada, R., Oshima, N., Suzuki, T., Ando, T., Aoki, T., and Fujita, K.: Increasing dust emission from ice free terrain in southeastern Greenland since 2000, Polar Sci., 100599, https://doi.org/10.1016/j.polar.2020.100599, 2020.

AICC - Predictive Services - Intelligence / Reports: https://fire.ak.blm.gov/predsvcs/intel.php, last access: 23 June 2021.

Bamber, J.: Greenland $5 \mathrm{~km}$ DEM, Ice Thickness, and Bedrock Elevation Grids, Version 1, https://doi.org/10.5067/01A10Z9BM7KP, 2001.

Bigler, M., Svensson, A., Kettner, E., Vallelonga, P., Nielsen, M. E., and Steffensen, J. P.: Optimization of High-Resolution 25 Continuous Flow Analysis for Transient Climate Signals in Ice Cores, Environ. Sci. Technol., 45, 4483-4489, https://doi.org/10.1021/es200118j, 2011.

Boichu, M., Favez, O., Riffault, V., Petit, J.-E., Zhang, Y., Brogniez, C., Sciare, J., Chiapello, I., Clarisse, L., Zhang, S., PujolSöhne, N., Tison, E., Delbarre, H., and Goloub, P.: Large-scale particulate air pollution and chemical fingerprint of volcanic sulfate aerosols from the 2014-2015 Holuhraun flood lava eruption of Bárðarbunga volcano (Iceland), Atmospheric Chem. Phys., 19, 14253-14287, https://doi.org/10.5194/acp-19-14253-2019, 2019.

Brantley, S. R.: The eruption of Redoubt Volcano, Alaska, December 14,1989-August 31, 1990, 1990.

Bullard, J. E. and Mockford, T.: Seasonal and decadal variability of dust observations in the Kangerlussuaq area, west Greenland, Arct. Antarct. Alp. Res., 50, S100011, https://doi.org/10.1080/15230430.2017.1415854, 2018. 
https://doi.org/10.5194/cp-2021-99

Preprint. Discussion started: 16 August 2021

(c) Author(s) 2021. CC BY 4.0 License.
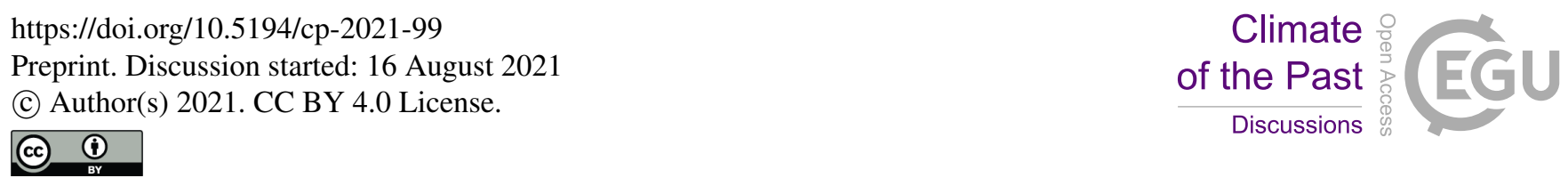

Canadian Forest Service: . 2013. Canadian National Fire Database - Agency Fire Data. Natural Resources Canada, Canadian Forest Service, Northern Forestry Centre, Edmonton, Alberta. http://cwfis.cfs.nrcan.gc.ca/en_CA/nfdb, 2013.

Casadevall, T. J.: The 1989-1990 eruption of Redoubt Volcano, Alaska: impacts on aircraft operations, J. Volcanol. Geotherm. Res., 62, 301-316, https://doi.org/10.1016/0377-0273(94)90038-8, 1994.

5 Dallmayr, R., Goto-Azuma, K., Kjær, H. A., Azuma, N., Takata, M., Schüpbach, S., and Hirabayashi, M.: A High-Resolution Continuous Flow Analysis System for Polar Ice Cores, Bull. Glaciol. Res., 34, 11-20, https://doi.org/10.5331/bgr.16R03, 2016.

Dansgaard, W.: Stable isotopes in precipitation, Tellus, 16, 436-468, https://doi.org/10.3402/tellusa.v16i4.8993, 1964.

Du, Z., Xiao, C., Zhang, Q., Li, C., Wang, F., Liu, K., and Ma, X.: Climatic and environmental signals recorded in the EGRIP snowpit, Greenland, Environ. Earth Sci., 78, 170, https://doi.org/10.1007/s12665-019-8177-4, 2019.

Fischer, H., Wagenbach, D., and Kipfstuhl, J.: Sulfate and nitrate firn concentrations on the Greenland ice sheet: 2 . Temporal anthropogenic deposition changes, J. Geophys. Res. Atmospheres, 103, 21935-21942, https://doi.org/10.1029/98JD01886, 1998.

Fischer, H., Siggaard-Andersen, M.-L., Ruth, U., Röthlisberger, R., and Wolff, E.: Glacial/interglacial changes in mineral dust 15 and sea-salt records in polar ice cores: Sources, transport, and deposition, Rev. Geophys., 45, https://doi.org/10.1029/2005RG000192, 2007.

Frey, M. M., Bales, R. C., and McConnell, J. R.: Climate sensitivity of the century-scale hydrogen peroxide (H2O2) record preserved in 23 ice cores from West Antarctica, J. Geophys. Res. Atmospheres, 111, https://doi.org/10.1029/2005JD006816, 2006.

20 Fuhrer, K., Neftel, A., Anklin, M., Staffelbach, T., and Legrand, M.: High-resolution ammonium ice core record covering a complete glacial-interglacial cycle, J. Geophys. Res. Atmospheres, 101, 4147-4164, https://doi.org/10.1029/95JD02903, 1996.

Gao, C., Robock, A., and Ammann, C.: Volcanic forcing of climate over the past 1500 years: An improved ice core-based index for climate models, J. Geophys. Res. Atmospheres, 113, https://doi.org/10.1029/2008JD010239, 2008.

Gfeller, G., Fischer, H., Bigler, M., Schüpbach, S., Leuenberger, D., and Mini, O.: Representativeness and seasonality of major ion records derived from NEEM firn cores, The Cryosphere, 8, 1855-1870, https://doi.org/10.5194/tc-8-1855-2014, 2014.

Grieman, M. M., Aydin, M., Isaksson, E., Schwikowski, M., and Saltzman, E. S.: Aromatic acids in an Arctic ice core from Svalbard: a proxy record of biomass burning, Clim. Past, 14, 637-651, https://doi.org/10.5194/cp-14-637-2018, 2018 a.

Grieman, M. M., Aydin, M., McConnell, J. R., and Saltzman, E. S.: Burning-derived vanillic acid in an Arctic ice core from Tunu, northeastern Greenland, Clim. Past, 14, 1625-1637, https://doi.org/10.5194/cp-14-1625-2018, 2018 b.

30 Hawley, R. L., Courville, Z. R., Kehrl, L. M., Lutz, E. R., Osterberg, E. C., Overly, T. B., and Wong, G. J.: Recent accumulation variability in northwest Greenland from ground-penetrating radar and shallow cores along the Greenland Inland Traverse, J. Glaciol., 60, 375-382, https://doi.org/10.3189/2014JoG13J141, 2014.

Hreinsdóttir, S., Sigmundsson, F., Roberts, M. J., Björnsson, H., Grapenthin, R., Arason, P., Árnadóttir, T., Hólmjárn, J., Geirsson, H., Bennett, R. A., Gudmundsson, M. T., Oddsson, B., Ófeigsson, B. G., Villemin, T., Jónsson, T., Sturkell, E., 35 Höskuldsson, Á., Larsen, G., Thordarson, T., and Óladóttir, B. A.: Volcanic plume height correlated with magma-pressure change at Grímsvötn Volcano, Iceland, Nat. Geosci., 7, 214-218, https://doi.org/10.1038/ngeo2044, 2014. 
https://doi.org/10.5194/cp-2021-99

Preprint. Discussion started: 16 August 2021

(c) Author(s) 2021. CC BY 4.0 License.

Johnsen, S. J., Dansgaard, W., and White, J. W. C.: The origin of Arctic precipitation under present and glacial conditions, Tellus B Chem. Phys. Meteorol., 41, 452-468, https://doi.org/10.3402/tellusb.v41i4.15100, 1989.

Kang, J.-H., Hwang, H., Hong, S. B., Hur, S. D., Choi, S.-D., Lee, J., and Hong, S.: Mineral dust and major ion concentrations in snowpit samples from the NEEM site, Greenland, Atmos. Environ., 120, 137-143, 5 https://doi.org/10.1016/j.atmosenv.2015.08.062, 2015.

Karlsson, N. B., Razik, S., Hörhold, M., Winter, A., Steinhage, D., Binder, T., and Eisen, O.: Surface accumulation in Northern Central Greenland during the last 300 years, Ann. Glaciol., 61, 214-224, https://doi.org/10.1017/aog.2020.30, 2020.

Kaufmann, P. R., Federer, U., Hutterli, M. A., Bigler, M., Schüpbach, S., Ruth, U., Schmitt, J., and Stocker, T. F.: An Improved Continuous Flow Analysis System for High-Resolution Field Measurements on Ice Cores, Environ. Sci. Technol., 42, 8044-

10 8050, https://doi.org/10.1021/es8007722, 2008.

Kawamura, K., Izawa, Y., Mochida, M., and Shiraiwa, T.: Ice core records of biomass burning tracers (levoglucosan and dehydroabietic, vanillic and p-hydroxybenzoic acids) and total organic carbon for past 300years in the Kamchatka Peninsula, Northeast Asia, Geochim. Cosmochim. Acta, 99, 317-329, https://doi.org/10.1016/j.gca.2012.08.006, 2012.

Kerminen, V.-M., Niemi, J. V., Timonen, H., Aurela, M., Frey, A., Carbone, S., Saarikoski, S., Teinilä, K., Hakkarainen, J.,

15 Tamminen, J., Vira, J., Prank, M., Sofiev, M., and Hillamo, R.: Characterization of a volcanic ash episode in southern Finland caused by the Grimsvötn eruption in Iceland in May 2011, Atmospheric Chem. Phys., 11, 12227-12239, https://doi.org/10.5194/acp-11-12227-2011, 2011.

Kjær, H. A., Vallelonga, P., Svensson, A., Kristensen, M. E. L., Tibuleac, C., and Bigler, M.: Continuous Flow Analysis Method for Determination of Dissolved Reactive Phosphorus in Ice Cores, Environ. Sci. Technol., 47, 12325-12332, https://doi.org/10.1021/es402274z, 2013.

Kjær, H. A., Vallelonga, P., Svensson, A., Elleskov L. Kristensen, M., Tibuleac, C., Winstrup, M., and Kipfstuhl, S.: An Optical Dye Method for Continuous Determination of Acidity in Ice Cores, Environ. Sci. Technol., 50, 10485-10493, https://doi.org/10.1021/acs.est.6b00026, 2016.

Kjær, H. A., Lolk Hauge, L., Simonsen, M., Yoldi, Z., Koldtoft, I., Hörholdt, M., Freitag, J., Kipfstuhl, S., Svensson, A., and 25 Vallelonga, P.: A portable Lightweight In Situ Analysis (LISA) box for ice and snow analysis, Cryosphere Discuss., 1-19, https://doi.org/10.5194/tc-2021-51, 2021a.

Kjær, H. A., Zens, P., Edwards, R., Olesen, M., Mottram, R., Lewis, G., Terkelsen Holme, C., Black, S., Holst Lund, K., Schmidt, M., Dahl-Jensen, D., Vinther, B., Svensson, A., Karlsson, N., Box, J. E., Kipfstuhl, S., and Vallelonga, P.: Recent North Greenland temperature warming and accumulation, Cryosphere Discuss., 1-27, https://doi.org/10.5194/tc-2020-337, $2021 b$.

Kuramoto, T., Goto-Azuma, K., Hirabayashi, M., Miyake, T., Motoyama, H., Dahl-Jensen, D., and Steffensen, J. P.: Seasonal variations of snow chemistry at NEEM, Greenland, Ann. Glaciol., 52, 193-200, https://doi.org/10.3189/172756411797252365, 2011.

Laepple, T., Hörhold, M., Münch, T., Freitag, J., Wegner, A., and Kipfstuhl, S.: Layering of surface snow and firn at Kohnen

35 Station, Antarctica: Noise or seasonal signal?, J. Geophys. Res. Earth Surf., 121, 1849-1860, https://doi.org/10.1002/2016JF003919, 2016. 
https://doi.org/10.5194/cp-2021-99

Preprint. Discussion started: 16 August 2021

(c) Author(s) 2021. CC BY 4.0 License.

(c) (i)

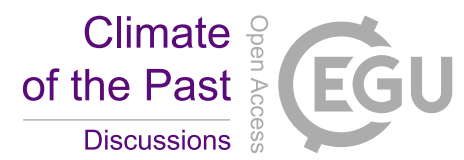

Legrand, M., Angelis, M. D., Staffelbach, T., Neftel, A., and Stauffer, B.: Large perturbations of ammonium and organic acids content in the summit-Greenland Ice Core. Fingerprint from forest fires?, Geophys. Res. Lett., 19, 473-475, https://doi.org/10.1029/91GL03121, 1992.

Legrand, M., de Angelis, M., Cachier, H., and Gaudichet, A.: Boreal Biomass Burning Over the Last 80 Years Recorded in a 5 Summit-Greenland Ice Core, in: Ice Core Studies of Global Biogeochemical Cycles, Berlin, Heidelberg, 347-360, https://doi.org/10.1007/978-3-642-51172-1_18, 1995.

Legrand, M., McConnell, J., Fischer, H., Wolff, E. W., Preunkert, S., Arienzo, M., Chellman, N., Leuenberger, D., Maselli, O., Place, P., Sigl, M., Schüpbach, S., and Flannigan, M.: Boreal fire records in Northern Hemisphere ice cores: a review, Clim Past, 27, 2016.

10 Marius Folden Simonsen, Giovanni Baccolo, Thomas Blunier, Alejandra Burunda, Barbara Delmonte, Robert Frei, Steven Goldstein, Aslak Grindsted, Helle Astrid Kjær, Todd Sowers, Anders Svensson, Bo Vinther, Diana Vladimorova, Gisela Winckler, Mai Winstrup, and Paul Vallelonga: Ice core dust particle sizes reveal past ice sheet extent in East Greenland, Nat. Commun., accepted, 2019.

McIlhattan, E. A., Pettersen, C., Wood, N. B., and L'Ecuyer, T. S.: Satellite observations of snowfall regimes over the 15 Greenland Ice Sheet, The Cryosphere, 14, 4379-4404, https://doi.org/10.5194/tc-14-4379-2020, 2020.

Moxnes, E. D., Kristiansen, N. I., Stohl, A., Clarisse, L., Durant, A., Weber, K., and Vogel, A.: Separation of ash and sulfur dioxide during the 2011 Grímsvötn eruption, J. Geophys. Res. Atmospheres, 119, 7477-7501, https://doi.org/10.1002/2013JD021129, 2014.

Nagatsuka, N., Goto-Azuma, K., Tsushima, A., Fujita, K., Matoba, S., Onuma, Y., Dallmayr, R., Kadota, M., Hirabayashi,

20 M., Ogata, J., Ogawa-Tsukagawa, Y., Kitamura, K., Minowa, M., Komuro, Y., Motoyama, H., and Aoki, T.: Variations in mineralogy of dust in an ice core obtained from northwestern Greenland over the past 100 years, Clim. Past, 17, 1341-1362, https://doi.org/10.5194/cp-17-1341-2021, 2021.

Neftel, A.: The Record of Gases and Reactive Species in Ice Cores, and Problems of Interpretation, in: Chemical Exchange Between the Atmosphere and Polar Snow, 45-69, 1996.

25 Palais, J. M., Germani, M. S., and Zielinski, G. A.: Inter-hemispheric Transport of Volcanic Ash from a 1259 A.D. Volcanic Eruption to the Greenland and Antarctic Ice Sheets, Geophys. Res. Lett., 19, 801-804, https://doi.org/10.1029/92GL00240, 1992.

Parisien, M.-A., Snetsinger, S., Greenberg, J. A., Nelson, C. R., Schoennagel, T., Dobrowski, S. Z., Moritz, M. A., Parisien, M.-A., Snetsinger, S., Greenberg, J. A., Nelson, C. R., Schoennagel, T., Dobrowski, S. Z., and Moritz, M. A.: Spatial variability

30 in wildfire probability across the western United States, Int. J. Wildland Fire, 21, 313-327, https://doi.org/10.1071/WF11044, 2012.

Parvin, F., Seki, O., Fujita, K., Iizuka, Y., Matoba, S., Ando, T., and Sawada, K.: Assessment for paleoclimatic utility of biomass burning tracers in SE-Dome ice core, Greenland, Atmos. Environ., 196, 86-94, https://doi.org/10.1016/j.atmosenv.2018.10.012, 2019.

35 Pasteris, D. R., McConnell, J. R., and Edwards, R.: High-Resolution, Continuous Method for Measurement of Acidity in Ice Cores, Environ. Sci. Technol., 46, 1659-1666, https://doi.org/10.1021/es202668n, 2012.

Petersen, G. N., Bjornsson, H., and Arason, P.: Two weather radar time series of the altitude of the volcanic plume during the May 2011 eruption of Grímsvötn, Iceland, 7, 2011. 
https://doi.org/10.5194/cp-2021-99

Preprint. Discussion started: 16 August 2021

(c) Author(s) 2021. CC BY 4.0 License.

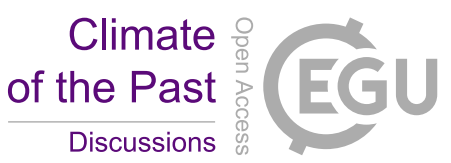

Pokhrel, A., Kawamura, K., Kunwar, B., Ono, K., Tsushima, A., Seki, O., Matoba, S., and Shiraiwa, T.: Ice core records of levoglucosan and dehydroabietic and vanillic acids from Aurora Peak in Alaska since the 1660s: a proxy signal of biomassburning activities in the North Pacific Rim, Atmospheric Chem. Phys., 20, 597-612, https://doi.org/10.5194/acp-20-597-2020, 2020.

5 Quinn, P. K., Shaw, G., Andrews, E., Dutton, E. G., Ruoho-Airola, T., and Gong, S. L.: Arctic haze: current trends and knowledge gaps, Tellus B Chem. Phys. Meteorol., 59, 99-114, https://doi.org/10.1111/j.1600-0889.2006.00236.x, 2007.

Rasmussen, S. O., Abbott, P. M., Blunier, T., Bourne, A. J., Brook, E., Buchardt, S. L., Buizert, C., Chappellaz, J., Clausen, H. B., Cook, E., Dahl-Jensen, D., Davies, S. M., Guillevic, M., Kipfstuhl, S., Laepple, T., Seierstad, I. K., Severinghaus, J. P., Steffensen, J. P., Stowasser, C., Svensson, A., Vallelonga, P., Vinther, B. M., Wilhelms, F., and Winstrup, M.: A first 10 chronology for the North Greenland Eemian Ice Drilling (NEEM) ice core, Clim. Past, 9, 2713-2730, https://doi.org/10.5194/cp-9-2713-2013, 2013.

Rhodes, R. H., Yang, X., and Wolff, E. W.: Sea Ice Versus Storms: What Controls Sea Salt in Arctic Ice Cores?, Geophys. Res. Lett., 45, 5572-5580, https://doi.org/10.1029/2018GL077403, 2018.

Robock, A. and Free, M. P.: Ice cores as an index of global volcanism from 1850 to the present, J. Geophys. Res. Atmospheres, 100, 11549-11567, https://doi.org/10.1029/95JD00825, 1995.

Röthlisberger, R., Bigler, M., Hutterli, M., Sommer, S., Stauffer, B., Junghans, H. G., and Wagenbach, D.: Technique for Continuous High-Resolution Analysis of Trace Substances in Firn and Ice Cores, Environ. Sci. Technol., 34, 338-342, https://doi.org/10.1021/es9907055, 2000.

Ruth, U., Wagenbach, D., Bigler, M., Steffensen, J. P., Röthlisberger, R., and Miller, H.: High-resolution microparticle profiles

20 at NorthGRIP, Greenland: case studies of the calcium-dust relationship, Ann. Glaciol., 35, 237-242, https://doi.org/10.3189/172756402781817347, 2002.

Savarino, J. and Legrand, M.: High northern latitude forest fires and vegetation emissions over the last millennium inferred from the chemistry of a central Greenland ice core, J. Geophys. Res. Atmospheres, 103, 8267-8279, https://doi.org/10.1029/97JD03748, 1998.

25 Schumann, U., Weinzierl, B., Reitebuch, O., Schlager, H., Minikin, A., Forster, C., Baumann, R., Sailer, T., Graf, K., Mannstein, H., Voigt, C., Rahm, S., Simmet, R., Scheibe, M., Lichtenstern, M., Stock, P., Rüba, H., Schäuble, D., Tafferner, A., Rautenhaus, M., Gerz, T., Ziereis, H., Krautstrunk, M., Mallaun, C., Gayet, J.-F., Lieke, K., Kandler, K., Ebert, M., Weinbruch, S., Stohl, A., Gasteiger, J., Groß, S., Freudenthaler, V., Wiegner, M., Ansmann, A., Tesche, M., Olafsson, H., and Sturm, K.: Airborne observations of the Eyjafjalla volcano ash cloud over Europe during air space closure in April and May 2010, Atmospheric Chem. Phys., 11, 2245-2279, https://doi.org/10.5194/acp-11-2245-2011, 2011.

Schüpbach, S., Fischer, H., Bigler, M., Erhardt, T., Gfeller, G., Leuenberger, D., Mini, O., Mulvaney, R., Abram, N. J., Fleet, L., Frey, M. M., Thomas, E., Svensson, A., Dahl-Jensen, D., Kettner, E., Kjaer, H., Seierstad, I., Steffensen, J. P., Rasmussen, S. O., Vallelonga, P., Winstrup, M., Wegner, A., Twarloh, B., Wolff, K., Schmidt, K., Goto-Azuma, K., Kuramoto, T., Hirabayashi, M., Uetake, J., Zheng, J., Bourgeois, J., Fisher, D., Zhiheng, D., Xiao, C., Legrand, M., Spolaor, A., Gabrieli, J.,

35 Barbante, C., Kang, J.-H., Hur, S. D., Hong, S. B., Hwang, H. J., Hong, S., Hansson, M., Iizuka, Y., Oyabu, I., Muscheler, R., Adolphi, F., Maselli, O., McConnell, J., and Wolff, E. W.: Greenland records of aerosol source and atmospheric lifetime changes from the Eemian to the Holocene, Nat. Commun., 9, 1-10, https://doi.org/10.1038/s41467-018-03924-3, 2018.

Scott, W. E. and McGimsey, R. G.: Character, mass, distribution, and origin of tephra-fall deposits of the 1989-1990 eruption of redoubt volcano, south-central Alaska, J. Volcanol. Geotherm. Res., 62, 251-272, https://doi.org/10.1016/0377- 
https://doi.org/10.5194/cp-2021-99

Preprint. Discussion started: 16 August 2021

(c) Author(s) 2021. CC BY 4.0 License.
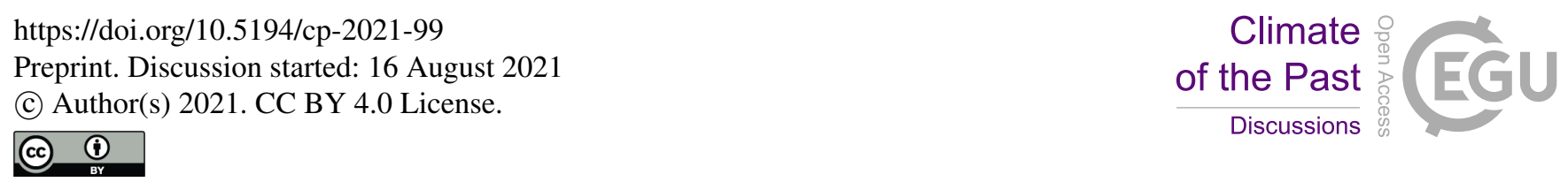

Segato, D., Villoslada Hidalgo, M. D. C., Edwards, R., Barbaro, E., Vallelonga, P., Kjær, H. A., Simonsen, M., Vinther, B., Maffezzoli, N., Zangrando, R., Turetta, C., Battistel, D., Vésteinsson, O., Barbante, C., and Spolaor, A.: 5\&thinsp;kyr of fire history in the High North Atlantic Region: natural variability and ancient human forcing, Clim. Past Discuss., 1-22, https://doi.org/10.5194/cp-2021-26, 2021.

5 Sigg, A. and Neftel, A.: Seasonal Variations in Hydrogen Peroxide in Polar Ice Cores, Ann. Glaciol., 10, 157-162, https://doi.org/10.3189/S0260305500004353, 1988.

Sigg, Andreas., Fuhrer, Katrin., Anklin, Martin., Staffelbach, Thomas., and Zurmuehle, Daniel.: A continuous analysis technique for trace species in ice cores, Environ. Sci. Technol., 28, 204-209, https://doi.org/10.1021/es00051a004, $1994 \mathrm{a}$.

Sigg, Andreas., Fuhrer, Katrin., Anklin, Martin., Staffelbach, Thomas., and Zurmuehle, Daniel.: A continuous analysis technique for trace species in ice cores, Environ. Sci. Technol., 28, 204-209, https://doi.org/10.1021/es00051a004, 1994b.

Sigl, M., Fudge, T. J., Winstrup, M., Cole-Dai, J., Ferris, D., McConnell, J. R., Taylor, K. C., Welten, K. C., Woodruff, T. E., Adolphi, F., Bisiaux, M., Brook, E. J., Buizert, C., Caffee, M. W., Dunbar, N. W., Edwards, R., Geng, L., Iverson, N., Koffman, B., Layman, L., Maselli, O. J., McGwire, K., Muscheler, R., Nishiizumi, K., Pasteris, D. R., Rhodes, R. H., and Sowers, T. A.: The WAIS Divide deep ice core WD2014 chronology - Part 2: Annual-layer counting (0-31 ka BP), Clim. Past, 12, 769-786, 2016.

Simonsen, M. F., Cremonesi, L., Baccolo, G., Bosch, S., Delmonte, B., Erhardt, T., Kjær, H. A., Potenza, M., Svensson, A., and Vallelonga, P.: Particle shape accounts for instrumental discrepancy in ice core dust size distributions, Clim. Past, 14, 601-608, https://doi.org/10.5194/cp-14-601-2018, 2018.

S.R. Gíslason, G. Stefánsdóttir, M.A. Pfeffer, S. Barsotti, Th. Jóhannsson, I. Galeczka, E. Bali, O. Sigmarsson, A. Stefánsson, 20 N.S. Keller, Á. Sigurdsson, B. Bergsson, B. Galle, V.C. Jacobo, S. Arellano, A. Aiuppa, E.B. Jónasdóttir, E.S. Eiríksdóttir, S. Jakobsson, G.H. Guðfinnsson, S.A. Halldórsson, H. Gunnarsson, B. Haddadi, I. Jónsdóttir, Th. Thordarson, M. Riishuus, Th. Högnadóttir, T. Dürig, G.B.M. Pedersen, Á. Höskuldsson, and M.T. Gudmundsson: Environmental pressure from the 201415 eruption of Bárðarbunga volcano, Iceland, Geochem. Perspect. Lett., 1, 84-93, https://doi.org/10.7185/geochemlet.1509, 2015 .

25 Svensson, A., Andersen, K. K., Bigler, M., Clausen, H. B., Dahl-Jensen, D., Davies, S. M., Johnsen, S. J., Muscheler, R., Parrenin, F., Rasmussen, S. O., Röthlisberger, R., Seierstad, I., Steffensen, J. P., and Vinther, B. M.: A 60000 year greenland stratigraphic ice core chronology, Clim. Past, 4, 47-57, 2008.

Thomas, H. E. and Prata, A. J.: Sulphur dioxide as a volcanic ash proxy during the April-May 2010 eruption of Eyjafjallajökull Volcano, Iceland, Atmospheric Chem. Phys., 11, 6871-6880, https://doi.org/10.5194/acp-11-6871-2011, 2011.

30 Thordarson, T. and Larsen, G.: Volcanism in Iceland in historical time: Volcano types, eruption styles and eruptive history, J. Geodyn., 43, 118-152, https://doi.org/10.1016/j.jog.2006.09.005, 2007.

Vallelonga, P., Christianson, K., Alley, R. B., Anandakrishnan, S., Christian, J. E. M., Dahl-Jensen, D., Gkinis, V., Holme, C., Jacobel, R. W., Karlsson, N. B., Keisling, B. A., Kipfstuhl, S., Kjær, H. A., Kristensen, M. E. L., Muto, A., Peters, L. E., Popp, T., Riverman, K. L., Svensson, A. M., Tibuleac, C., Vinther, B. M., Weng, Y., and Winstrup, M.: Initial results from 35 geophysical surveys and shallow coring of the Northeast Greenland Ice Stream (NEGIS), Cryosphere, 8, 1275-1287, https://doi.org/10.5194/tc-8-1275-2014, 2014.

Winstrup, M., Vallelonga, P., Kjær, H. A., Fudge, T. J., Lee, J. E., Riis, M. H., Edwards, R., Bertler, N. A. N., Blunier, T., Brook, E. J., Buizert, C., Ciobanu, G., Conway, H., Dahl-Jensen, D., Ellis, A., Emanuelsson, B. D., Hindmarsh, R. C. A., Keller, E. D., Kurbatov, A. V., Mayewski, P. A., Neff, P. D., Pyne, R. L., Simonsen, M. F., Svensson, A., Tuohy, A., 
https://doi.org/10.5194/cp-2021-99

Preprint. Discussion started: 16 August 2021

(c) Author(s) 2021. CC BY 4.0 License.

(c) (1)

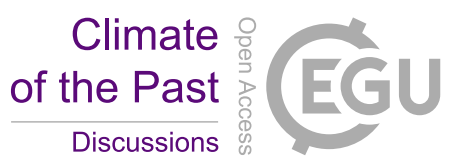

Waddington, E. D., and Wheatley, S.: A 2700-year annual timescale and accumulation history for an ice core from Roosevelt Island, West Antarctica, Clim. Past, 15, 751-779, https://doi.org/Winstrup, Mai; Vallelonga, Paul; Kjær, Helle A.; Fudge, Tyler J.; Lee, James E.; Riis, Marie H.; Edwards, Ross; Bertler, Nancy A.N.; Blunier, Thomas; Brook, Ed J.; Buizert, Christo; Ciobanu, Gabriela; Conway, Howard; Dahl-Jensen, Dorthe; Ellis, Aja; Emanuelsson, B. Daniel; Hindmarsh, Richard C.A.

5 ORCID: https://orcid.org/0000-0003-1633-2416 <https://orcid.org/0000-0003-1633-2416>; Keller, Elizabeth D.; Kurbatov, Andrei V.; Mayewski, Paul A.; Neff, Peter D.; Pyne, Rebecca L.; Simonsen, Marius F.; Svensson, Anders; Tuohy, Andrea; Waddington, Edwin D.; Wheatley, Sarah. 2019 A 2700-year annual timescale and accumulation history for an ice core from Roosevelt Island, West Antarctica. Climate of the Past, 15. 751-779. https://doi.org/10.5194/cp-15-751-2019 <https://doi.org/10.5194/cp-15-751-2019>, 2019.

10 Zennaro, P., Kehrwald, N., McConnell, J. R., Schüpbach, S., Maselli, O. J., Marlon, J., Vallelonga, P., Leuenberger, D., Zangrando, R., Spolaor, A., Borrotti, M., Barbaro, E., Gambaro, A., and Barbante, C.: Fire in ice: two millennia of boreal forest fire history from the Greenland NEEM ice core, Clim. Past, 10, 1905-1924, https://doi.org/10.5194/cp-10-1905-2014, 2014. 